\title{
R-Cadherin Expression in the Developing and Adult Zebrafish Visual System
}

\author{
Q. LIU, ${ }^{1 *}$ K.L. SANBORN, ${ }^{2}$ N. COBB, ${ }^{2}$ P.A. RAYMOND, ${ }^{1}$ AND J .A. MARRS ${ }^{2}$ \\ ${ }^{1}$ Department of Anatomy and Cell Biology, 4610 Medical Science II, University of Michigan, \\ Ann Arbor, Michigan 48109 \\ ${ }^{2}$ Department of Medicine, I ndiana U niversity Medical Center, I ndianapolis, I ndiana 46202
}

\begin{abstract}
Cell adhesion molecules in the cadherin family have been implicated in histogenesis and maintenance of cellular structure and function in several organs. Zebrafish have emerged as an important new developmental model, but only three zebrafish cadherin molecules have been identified to date ( $\mathrm{N}$-cadherin, paraxial protocadherin, and $\mathrm{VN}$-cadherin). We began a systematic study to identify other zebrafish cadherins by screening zebrafish cDNA libraries using an antibody raised to the cytoplasmic domain of mouse E-cadherin. Here, we report a partial cDNA with extensive sequence homology to R-cadherin. Spatial and temporal expression of this putative zebrafish R-cadherin was examined in embryos and adults by Northern analysis, RNase protection, and in situ hybridization. R-cadherin message increased during embryogenesis up to 80 hours postfertilization (hpf) and persisted in adults. In the embryonic brain, R-cadherin was first expressed in groups of cells in the diencephal on and pretectum. In adult zebrafish brain, R-cadherin continued to be expressed in several specific regions including primary visual targets. In the retina, R-cadherin was first detected at about 33 hours postfertilization in the retinal ganglion cell layer and the inner part of the inner nudear layer. Expression levels were highest during periods of axon outgrowth and synaptogenesis. Retrograde labeling of the optic nerve with $1,1^{\prime}$-dioctadecyl-3,3,3',3', tetramethylindocarbocyanine perchlorate (Dil) followed by in situ hybridization confirmed that a subset of retinal ganglion cells in the embryo expressed R-cadherin message. In the adult, R-cadherin expression continued in a subpopulation of retinal ganglion cells. These results suggest that R-cadherin-mediated adhesion plays a role in development and maintenance of neuronal connections in zebrafish visual system. J . Comp. Neurol . 410:303-319, 1999.

1999 Wiley-Liss, Inc.
\end{abstract}

Indexing terms: optic tectum; retinal ganglion cells; development; cell adhesion

The cadherins are a family of cell surface, $\mathrm{Ca}^{++}$ dependent, homophilic adhesion molecules (Hatta and Takeichi, 1986; Hatta et al., 1988; Takeichi, 1988, 1990, 1995) which play important roles in development of a variety of tissues including the brain (J essell, 1988; Takeichi, 1988, 1991). Cadherins form a large gene family, divided into classical cadherins (type I and type II) and more distantly related subfamilies, such as the protocadherins and the desmosomal cadherins (reviewed by Takeichi, 1995; Redies, 1997). R-cadherin, a member of the type I cadherin subfamily, was first cloned from chicken retina (I nuzuka et al., 1991), and subsequently mouse (Hutton et al., 1993; Matsunami et al., 1993), human (Tanihara et al., 1994), and Xenopus (Tashiro et al., 1995) orthologues were cloned. Among the classical cadherins, R-cadherin is most similar to N-cadherin (I nuzuka et al., 1991; Redies, 1997).

The distribution of R-cadherin in the vertebrate central nervous system has been examined in embryonic chicken
(I nuzuka et al., 1991; Redies et al., 1992, 1993; Gänzler and Redies, 1995; Arndt and Redies, 1996) and mouse (Matsunami and Takeichi, 1995; Stoykova et al., 1997). $\mathrm{R}$-cadherin is expressed in a spatiotemporally restricted pattern during the devel opment of chicken central nervous system (Redies et al., 1992, 1993). Cells expressing Rcadherin arefound within both motor and sensory systems in fiber tracts that are connected into functional circuits. Together with other cadherin molecules (e.g., the highly related $\mathrm{N}$-cadherin and other cadherins in the type II subfamily), R-cadherin-mediated adhesiveinteractions are

Grant sponsor: NIH; Grant numbers: EY11365, EY 04318, NRSA EY 06892.

*Correspondence to: Q. Liu, Department of Anatomy and Cell Biology, 4610 Medical Science II, University of Michigan, Ann Arbor, MI 48109. E-mail:qliu@umich.edu

Received 10J une 1998; Revised 12 February 1999; Accepted 26 February 1999 
thought to play a role in the segregation and formation of functionally separate brain nuclei and circuits (Redies et al., 1992, 1993; Matsunami and Takeichi, 1995; Redies, 1995; Redies and Takeichi, 1996; Redies, 1997; I noue et al., 1998). Both R- and N-cadherins are expressed in visual structures including the retina, the optic nerve, the pretectum, and the optic tectum in developing chicken (Matsunaga et al., 1988a,b; Gänzler and Redies, 1995; Redies and Takeichi, 1993a,b; Arndt and Redies, 1996; I noue and Sanes, 1997), suggesting that these cadherins may be involved in the development of the vertebrate visual system.

We used a polyclonal antibody directed against the highly conserved cytoplasmic domain of mouse E-cadherin, which was shown previously to recognize various cadherins from several different species (Marrs et al., 1993), to screen two zebrafish cDNA expression libraries. Two overlapping clones were obtained that showed extensive homology to chicken, mouse, and human R-cadherin. The expression pattern of this putative zebrafish Rcadherin was studied in both adult and embryonic tissues, with a special focus on the visual pathway. Data from these expression studies showed that R-cadherin message was highly expressed in the retina and presumptive visual structures in the brain during periods of retinal axon outgrowth and synaptogenesis, suggesting that zebrafish $\mathrm{R}$-cadherin plays a role in the development of the zebrafish visual system, similar to what was proposed for chicken.

\section{MATERIALS AND METHODS Animals}

Adult zebrafish were obtained from a local pet store and kept in 10 -gall on tanks at $28^{\circ} \mathrm{C}$ on a 12 -hour light/12-hour dark cycle. Zebrafish embryos were collected from our breeding colony and maintained according to standard procedures (Westerfield, 1996). Ages of the embryos are given as hours postfertilization (hpf) or days postfertilization. All animal-related procedures were conducted in accordance with the National Institute of Health Guide for the Care and Use of Laboratory Animals and were approved by the University Commitee on Use and Care of Animals.

\section{Immunoblotting}

Zebrafish tissues were dissected from adult animals and solubilized using a dounce homogenizer in sodium dodecyl sulfate (SDS) buffer (10 mM Tris- $\mathrm{HCl}, \mathrm{pH} 7.5,2 \mathrm{mM}$ EDTA, $1 \%$ SDS) at $100^{\circ} \mathrm{C}$. Samples were cleared by centrifugation at $13,000 \times \mathrm{g}$ at $4^{\circ} \mathrm{C}$. A bout $30 \mathrm{mg}$ of protein from each sample were separated on a 7.5\% SDS polyacrylamide gel, and gels were transferred to nitrocellulose (BioRad, Hercules, CA). Nitrocellulose membranes were rocked overnight in a blocking solution of $3 \%$ bovine serum albumin (BSA) and 5\% nonfat dry milk in TBST (10 mM Tris pH 7.5, 0.1 M N aCl, 0.1\% Tween 20). Membranes were then incubated in the primary antibody, ECAD-B.5, a rabbit polydonal antibody raised to a glutathione Stransferase (GST) fusion protein containing mouse Ecadherin cytoplasmic domain (Marrs et al., 1993), diluted $1: 10,000$ in blocking solution and rotated for 1 hour at room temperature. Blots were washed in TBST for 45 minutes, with five changes, then incubated for 1 hour at room temperature with anti-rabbit horseradish peroxidase (HRP)-conjugated secondary antibody, diluted 1:5,000 in blocking solution (Amersham, Arlington Heights, IL). Membranes were washed as above, processed for chemiluminescence ( $E C L$ kit, Amersham) and exposed to film (Kodak Bio-Max ML, Eastman Kodak, Rochester, NY).

\section{Library screening and DNA sequencing}

An adult zebrafish retinal CDNA expression library in $\lambda$ ZAP (generously provided by Dr. J ames Hurley, University of Washington) and a 15- to 19-hour zebrafish embryo cDNA expression library in $\lambda$ ZAP (generously provided by Dr. Bruce Appel, Vanderbilt University) were screened with antiserum ECAD-B.5 (see above) using standard protocols. Briefly, about $1 \times 10^{6}$ pfu were plated and lifted onto nitrocellulosefilters (Protran, Schleicher and Schuell, Keene, NH). Filters were washed twice with TBST, and then blocked overnight in TBST with 5\% nonfat dry milk. Primary antibody (ECAD-B.5) was diluted $1: 5,000$ in blocking solution, filters and antibody solution were seal ed into bags, and incubated, rotating, for 2 hours. Filters were washed in TBST five times for 10 minutes each. Alkaline phospatase-conjugated anti-rabbit secondary antibody (Gibco-BRL, Grand Island, NY) was diluted 1:5,000 and incubated with the filter, rotating for 2 hours. Filters were again washed with TBST five times for 10 minutes each, then washed twice with TBS (10 mM Tris-HCL pH 7.5, 0.1 $\mathrm{M} \mathrm{NaCl}$ ). Immunoreactive plaques were identified by using a chromogenic substrate solution $(60 \mu \mathrm{g} / \mathrm{ml}$ nitroblue tetrazolium (NBT) and $60 \mu \mathrm{g} / \mathrm{ml}$ 5-bromo-4-chloro-3indolyl phosphate (BCIP) in $100 \mathrm{mM}$ Tris- $\mathrm{HCl}, \mathrm{pH} 9.5,100$ $\mathrm{mM} \mathrm{NaCl}, 5 \mathrm{mM} \mathrm{M} \mathrm{gCl}$. Positive plaques were cored from the master plates and rescreened at least three times, or until all plaques were immunoreactive.

Plasmids were excised from $\lambda$ ZAP clones using excision protocols provided by the manufacturer (Stratagene, La J olla, CA), and purified using CsCl gradients (Sambrook et al., 1989). Nested deletions of plasmid DNA were prepared using exonuclease III according to manufacturer's protocols (Stratagene). These deletions and the full clone 9 and clone 39 cDNAs (putative R-cadherin CDNA) were sequenced using forward and reverse primers. Oligonucleotides were purchased (Operon, Alameda, CA) to complete and check the sequence. Automated sequencing using fluorescent-tagged nucleotides was performed using standard protocols at the Biotechnology Core Facility at Indiana University Medical Center. Both strands of cDNA clones 9 and 39 were compl etely sequenced.

Data bank searches were performed by BLAST at the National Center for Biotechnology Information web site (http://www.ncbi.nlm.nih.gov/). Sequence comparisons were performed using Vector NTI and Align X (InforMax Inc., North Bethesda, MD).

\section{Northern blot}

The embryos were first chilled in ice water, frozen in liquid nitrogen, then stored in $\mathrm{a}-80^{\circ} \mathrm{C}$ freezer for up to 1 week. For adult zebrafish, the animals were anesthetized in $0.02 \%$ methane tricaine sulfonate (MS-222, Sigma, St. Louis, MO), and killed by cervical transection. The brain was then quickly removed and frozen on dry ice. Isolation of total RNA from the brain began within 2 hours of removal. Total RNA was isolated from whole embryos at several stages (6-9, 12, and $24 \mathrm{hpf})$ and from adult zebrafish brain with Trizol Reagent (Gibco BRL) according to the manufacturer's instructions. The RNA $(12 \mu \mathrm{g})$ was separated in a $1 \%$ agarose/formal dehyde gel, transferred 
to nylon membrane (Boehringer Mannheim, Indianapolis, IN) and hybridized overnight at $65^{\circ} \mathrm{C}$ with ${ }^{32} \mathrm{P}$-labeled probe, transcribed from clone 9 using the Random Primed DNA Labeling Kit (Boehringer Mannheim). The membrane was washed twice with $2 \times$ SSC $(0.3 \mathrm{M}$ sodium chloride, $0.03 \mathrm{M}$ sodium citrate)/0.1\% SDS for 30 minutes each, once with $0.2 \times \mathrm{SSC} / 0.1 \%$ SDS at $65^{\circ} \mathrm{C}$ for 1 hour, then exposed overnight to XAR film (Kodak) at $-80^{\circ} \mathrm{C}$ with an intensifying screen.

\section{Probe synthesis and RNase protection assay}

The plasmid containing clone 9 (isolated from the retinal library) was linearized with Bam $\mathrm{HI}$ and a 437-bp fragment corresponding to the major portion of EC4 and one-third of EC5 of the zebrafish R-cadherin molecule (Fig. 1A) was subcloned into the Bam $\mathrm{HI}$ site of pBluescript $\mathrm{KS}+$ (Stratagene). The direction of the insert was determined by restriction mapping, and the CDNA was used as a template for synthesis of digoxigenin-labeled cR NA probes. After linearization with either $\mathrm{Notl}$ or Xho I, approximately $1 \mu \mathrm{g}$ of the template DNA was transcribed with T3 and T7 polymerases, to generate sense and antisense digoxigenin-labeled RNA probes, respectively, by the Genius System (Boehringer Mannheim).

For RNase protection assays, the RNase Protection Kit (Boehringer Mannheim) was used according to the manufacturer's instructions. Fifteen $\mu \mathrm{g}$ of total RNA from each of several stages of zebrafish embryos (37 hpf, $56 \mathrm{hpf}$, and $80 \mathrm{hpf}$ ) and adult zebrafish brain was hybridized overnight at $45^{\circ} \mathrm{C}$ with $400 \mathrm{pg}$ of the digoxigenin-labeled RNA probe. Following 30 minutes of RNase $\mathrm{T} 1$ digestion at $30^{\circ} \mathrm{C}$ and 15 minutes of proteinase $\mathrm{K}$ treatment at $37^{\circ} \mathrm{C}$, RNA was precipitated in ethanol and separated in a $4 \%$ polyacrylamide gel, containing $7 \mathrm{M}$ urea. The gel was blotted onto nylon membrane (Boehringer Mannheim) using MiniTrans-Blot Electrophoretic Transfer Cell (BioRad), and the RNA was cross-linked with UV light. Blots were developed using anti-digoxigenin Fab-fragment antibodies conjugated to alkaline phospatase and reacted with the CSPD (Disodium 3-(4-methoxyspiro[1,2-dioxetane-3,2' -(5' -chloro) tricyclo[3.3.1.13] decan)-4-yl ] phenyl phosphate) chemiluminescent substrate (Boehringer Mannheim), and exposed to Lumi-Film (Boehringer Mannheim). Two controls were carried out to check the specificity of the hybridization signal: RNA was hybridized with the sense probe, and target RNA was omitted from the hybridization reaction.

\section{Tissue preparation}

Animals were anesthetized in $0.02 \%$ MS-222, and adults were killed by cervical transection. The brain and eyes of adult fish or whole embryos and larvae were fixed for 1 hour in phosphate-buffered $4 \%$ paraformaldehyde $(\mathrm{pH}$ 7.4). The tissue was then rinsed in $0.1 \mathrm{M}$ phosphate buffer (pH 7.4) and prepared for cryosections as described previously (Barthel and Raymond, 1990; http://www.umich.edu/ $\sim$ praymond).

\section{In situ hybridization}

To generate cRNA sense and antisense probes for in situ hybridization, procedures were the same as described above, except that some probes were generated using the whole DNA insert of clone 9 as a template. For the synthesis of antisense $\mathrm{N}$-cadherin probes, the complete zebrafish $\mathrm{N}$-cadherin cDNA (a generous gift from Dr.
Benjamin Geiger at the Weizmann Institute of Science, Israel ) was cloned into pBS SK +, linearized with Hind III, and transcribed with T7 polymerase. Procedures used for in situ hybridization have been described in detail elsewhere (Barthel and Raymond, 1993; http://www.umich.edu/ $\sim$ praymond). Briefly, slides were treated with $0.01 \mathrm{mg} / \mathrm{ml}$ proteinase $\mathrm{K}$ (Boehringer Mannheim) at $37^{\circ} \mathrm{C}$ for $2 \mathrm{~min}$ utes, then incubated at room temperature in $0.1 \mathrm{M}$ triethanolamine, pH 8.0 (Sigma) for 3 minutes, followed by a 10 -minute rinse in $0.1 \mathrm{M}$ triethanolamine with $0.25 \%$ acetic anhydride (Sigma). The tissue was then dehydrated in a graded series of ethanols and air-dried. A pproximately $80 \mu$ l of hybridization solution, containing $2 \mu \mathrm{g}$ of CRNA, was placed on each slide, and the tissue was hybridized overnight at $56^{\circ} \mathrm{C}$. The next day, slides were washed in $2 \times$ SSC followed by $50 \%$ formamide in $2 \times$ SSC at $65^{\circ} \mathrm{C}$. Tissue was then treated with RNase A (Boehringer Mannheim) for 30 minutes. The method described by J owett et al. (1996) was used for wholemount in situ hybridization. For immunocytochemical detection of cRNA probes, antidigoxigenin $\mathrm{F}$ ab fragment antibodies conjugated to alkaline phosphatase were used with substrate NBT and BCIP solution (Boehringer Mannheim).

To verify the specificity of the full length R-cadherin cRNA probe, we also performed in situ hybridization using a shorter cRNA probe (transcribed from the $437 \mathrm{bp} \mathrm{Bam} \mathrm{HI}$ fragment of clone 9), and we compared the expression pattern of the R-cadherin probe with that of a probe generated from a full-length CDNA of zebrafish N-cadherin (Bitzur et al., 1994).

\section{Dil-labeling of retinal ganglion cells}

Dil (1,1'-dioctadecyl-3,3,3',3', tetramethylindocarbocyanine perchlorate) dissolved in N,N-dimethylformamide $(2.5 \mathrm{mg} / \mathrm{ml})$ was pressure-injected into the anterior portion of the optic tectum and pretectum of fixed embryos at 57-60 hpf (Burrill and Easter, 1994). The embryos were placed in $4 \%$ paraformaldehyde, and the Dil was allowed to transport overnight at $4^{\circ} \mathrm{C}$. The fluorescent Dil signal was then photoconverted to a permanent, dark brown reaction product by photoexcitation of the dye in the presence of $0.8 \mathrm{mg} / \mathrm{ml}$ diaminobenzidene (DAB; Sigma), in $0.1 \mathrm{M}$ phosphate buffer (pH 7.4), containing $5 \mathrm{mg} / \mathrm{ml}$ RNase inhibitor heparin (von Bartheld et al., 1990; Shimamura, 1995; Singleton and Casagrande, 1996). The embryos were then washed once in $0.1 \mathrm{M}$ phosphate buffer (pH 7.4) and prepared for cryosections as described previously (Barthel and Raymond, 1990). Procedures for in situ hybridization with the R-cadherin cRNA probe were the same as above.

Photomicrographs were digitized, processed, and formatted with Photoshop (Adobe, Mountain View, CA), and printed with a dye sublimation printer (Kodak XLS 8600 PS).

\section{RE SULTS Isolation of a putative zebrafish R-cadherin CDNA}

The cytoplasmic domain sequences of cadherin molecules are highly conserved. An antiserum raised to a GST fusion protein containing the mouse E-cadherin cytoplas- 


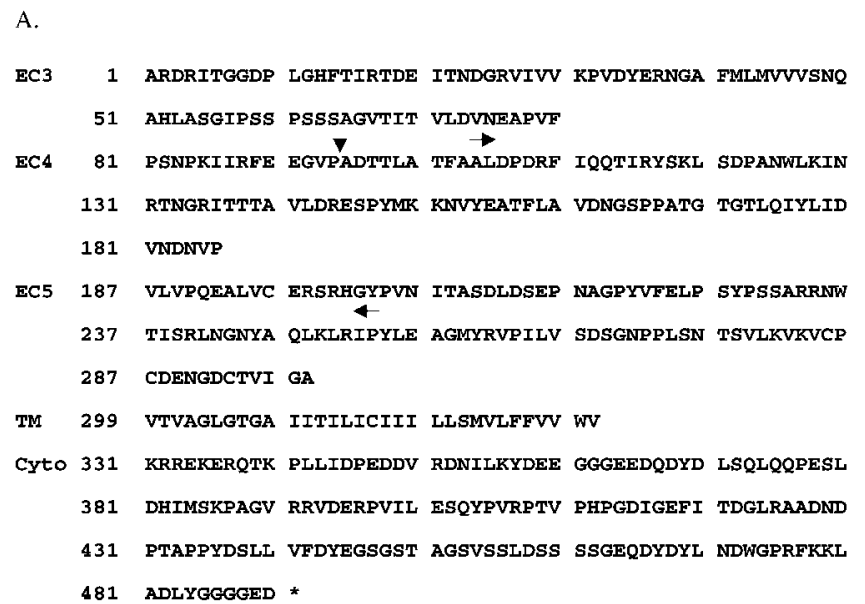

Fig. 1. Deduced amino acid sequence and comparison of a putative zebrafish R-cadherin homologue. A: Deduced amino acid sequence for clone 39, which begins in extracellular cadherin repeat domain 3 (EC3), continues through extracellular cadherin repeat domains 4 and 5 (EC4 and EC5), the transmembrane domain (TM), and the cytoplasmic domain (Cyto). The $5^{\prime}$-end of clone 9 coding sequence is indicated by the arrowhead above the $95^{\text {th }}$ amino acid (A). The pair of arrows between amino acids 106 and 352 indicates the corresponding Bam HI segment of clone 9 cDNA that was used as a template for the generation of the short CRNA probe. The asterisk at position 491 indicates the stop codon. B: Amino acid sequence comparison between the deduced amino acid sequence for the putative zebrafish R-cadherin

mic domain was shown previously to react with cadherins from several species (Marrs et al., 1993). This antiserum (ECAD-B .5) was tested on zebrafish by immunoblotting for reactivity with various zebrafish tissues, and cadherins were specifically detected in many tissues, including brain (data not shown). Because there is very little E-cadherin expression in the brain (Takeichi, 1988), this result strongly suggested that ECAD-B.5 reacts with zebrafish cadherins other than E-cadherin. Immunofluorescent preparations of cryostat sections of zebrafish eye showed that ECAD-B.5 specifically stained the retina (data not shown), indicating that this antiserum would be useful for screening a zebrafish retinal cDNA library to identify cDNAs encoding retinal cadherins.

CDNA libraries from adult zebrafish retina and a 15- to 19-hour zebrafish embryo were screened with the antiserum to mouse E-cadherin cytoplasmic domain. Two cDNAs (clone 9 from the retina library and clone 39 from the embryo library) were identified that encoded the same protein. Clone 9 cDNA is 1,982 bp. Clone 39 is the larger (3,188 bp), extending 282 bp on the $5^{\prime}$-end beyond that of clone 9, and containing 929 bp of additional 3' untranslated sequence. Clone 39 has 48 adenines at the 3 '-end and contains putative polyadenylation signals, suggesting that this CDNA is complete at the $3^{\prime}$-end. The deduced amino acid sequence (490 amino acids; Fig. 1) for the combined cDNA sequences was still incomplete, containing only part of the coding sequence for the protein. Classical cadherins generally have five extracellular domain repeats in the extracellular domain, and clone 39 cDN A sequences begin in the third repeat. The transmembrane domain and cytoplasmic domain sequences follow thethird, fourth, and fifth extracellular domain repeats.
(zR-cadherin), chicken R-cadherin (cR-cadherin), human R-cadherin (hR-cadherin), mouse R-cadherin (mR-cadherin), and zebrafish $\mathrm{N}$ cadherin (zN-cadherin). Comparisons were between published se quences (starting in EC3) and corresponding regions of the incomplete sequence of the putative zebrafish R-cadherin. Sequences highlighted by black boxes indicate residues that are common to all five sequences, and sequences highlighted by shadow boxes indicate amino acids that are identical in a majority of the sequences. Note that in many cases, sequences are shared in the four R-cadherin sequences but not in the zebrafish $\mathrm{N}$-cadherin sequence. Sequence comparisons were performed using Align X (InforMax Inc., North Bethesda, MD).

Nucleotide and deduced amino acid sequences were compared with sequences in DNA and protein databases. These sequences were found to be most similar to those of R-cadherin. The highest overall amino acid sequence identity was with chicken R-cadherin (77\% identity). When deduced amino acid sequences of this zebrafish cadherin were aligned with chicken R-cadherin, human R-cadherin, mouse R-cadherin, and zebrafish $\mathrm{N}$-cadherin amino acid sequences (Fig. 1B), high sequence identity was found between all four (black boxes). However, a large proportion of amino acids were shared between the putative zebrafish $\mathrm{R}$-cadherin sequence and R-cadherin from chicken, human and mouse, but not with zebrafish $\mathrm{N}$-cadherin.

A pattern emerged from pairwise amino acid sequence comparisons between several cadherins including the putative zebrafish R-cadherin sequences (Fig. 2). The Rcadherin sequences from zebrafish, chicken, mouse, human, and Xenopus (XmN-cadherin) were more closely related to one another than to other cadherin sequences (see shaded box in Fig. 2). R-cadherin is closely related to N-cadherin (I nuzuka et al., 1991; Matsunami et al., 1993; Redies, 1997). Comparison between $\mathrm{N}$-cadherin sequences from zebrafish, human, Xenopus, and mouse with the putative zebrafish R-cadherin sequence showed lower identity than that found with the other R-cadherin sequences. In contrast, pairwise comparisons of $\mathrm{N}$-cadherin sequences showed high identity (shaded box in Fig. 2). In summary, the amino acid sequence comparisons, together with the spatial and temporal in situ hybridization staining patterns (see below), strongly suggest that clone 9 and clone 39 are partial cDNAs that encode the zebrafish $\mathrm{R}$-cadherin orthologue. The larger cDNA sequence (clone 39) was submitted to GenBank (accession number: AF 124396). 
B.

zR-Cadherin $\mathrm{CR}$-Cadherin hR-Cadherin mR-Cadherin $\mathrm{zN}$-Cadherin

zR-Cadherin $\mathrm{cR}$-Cadherin $\mathrm{hR}$-Cadherin $\mathrm{mR}$-Cadherin zN-Cadherin

zR-Cadherin CR-Cadherin $\mathrm{hR}$-Cadherin mR-Cadherin $\mathrm{zN}-\mathrm{Cadherin}$

zR-Cadherin $\mathrm{CR}$-Cadherin $\mathrm{h}$-Cadherin $\mathrm{mR}$-Cadherin $\mathrm{zN}$-Cadherin

$\mathrm{zR}$-Cadherin cR-Cadherin hR-Cadherin $\mathrm{mR}$-Cadherin $\mathrm{zN}$-Cadherin

zR-Cadherin $\mathrm{CR}$-Cadherin $\mathrm{hR}$-Cadherin mR-Cadherin $\mathrm{zN}$-Cadherin

zR-Cadherin CR-Cadherin $\mathrm{h} R$-Cadherin $\mathrm{mR}$-Cadherin $\mathrm{zN}-\mathrm{Cadherin}$

zR-Cadherin CR-Cadherin $\mathrm{h}$-Cadherin $\mathrm{mR}$-Cadherin $\mathrm{zN}$-Cadherin

zR-Cadherin CR-Cadherin $\mathrm{hR}$-Cadherin $\mathrm{mR}$-Cadherin zN-Cadherin
(1)

(422)

(425)

(422)

(293)

(59)

(482)

(485)

(482)

(352)

(118)

(542)

(545)

(542)

(412)

(178)

(602)

(605)

(602)

(472)

(238)

(661)

(664)

(661)

(531)

(298)

(721)

(724)

$(721)$

(591)

(358)

(781)

(784)

(781)

(651)

$(418$

(841)

(844)

(841)

(711)

(477)

$(900)$

$(903)$

$(900)$

(771)
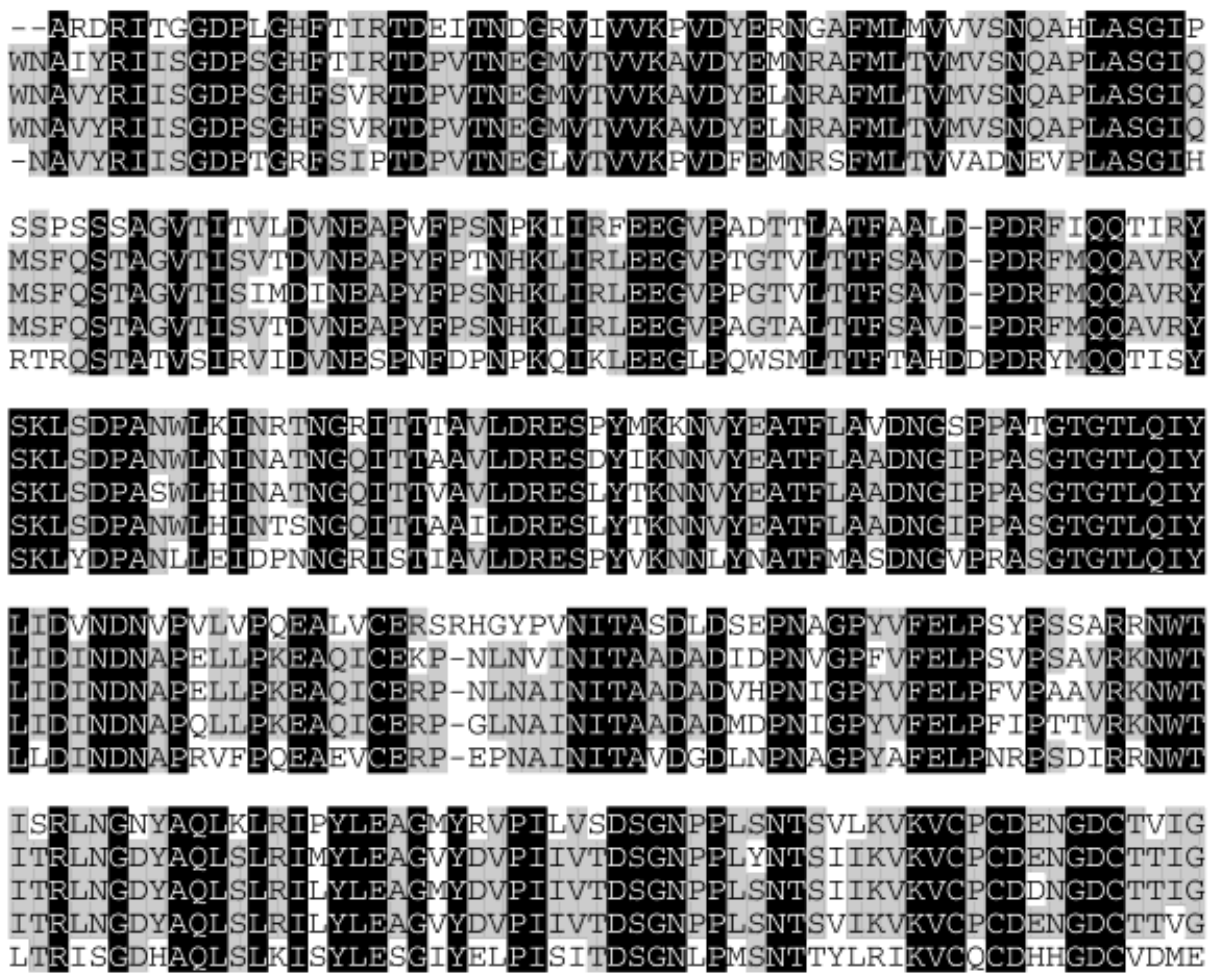

\section{AVTVAGLGTGAIITILICIIILLSMVLF FVVWTKRREKERQTKPLLIDPEDDVRDNILKY} AVAAAGLGTGAIIA ILICI I ILI TMVLLFVVWMKRREKERHTK OLLIDPEDDVRDN I LKY AVAAAGLGTGA IVA I LICILI LL TMVLLFVM MKRREKERHTKOLLIDPEDDVREK I LKY AVAAAGLGTGA IVA ILICIVILI IMVLLFVVWMKRREKERHTK QLLIDPEDDVRDNI IKY RIMAAGLGTGA I IA IL ICI I I LLVLVLMFVMWMKRRDKERQAKOLLIDPEDDVRDNILKY
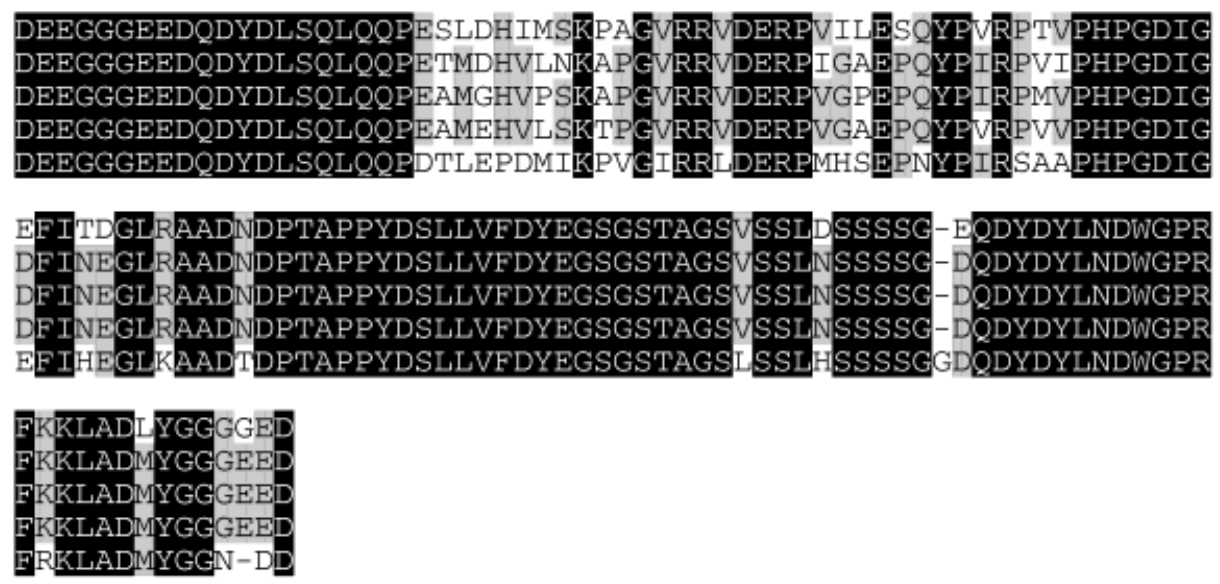

Figure 1 (continued)

\section{Characterization of R-cadherin mRNA expression during zebrafish embryogenesis}

Northern blot analysis detected a single transcript of approximately $4.9 \mathrm{~kb}$ in adult brain RNA samples (Fig. 3). RNase protection assays were used to examine expression levels in embryos. Controls showed that a band of the expected size was protected only in samples where RNA was included (Fig. 4), and the protected band was also absent when the sense probe was used (data not shown). $\mathrm{R}$-cadherin message was barely detectable in whole embryos at $37 \mathrm{hpf}$, the youngest stage examined (Fig. 4). By $56 \mathrm{hpf}$, message levels had increased, and highest expression levels were found in larvae at $80 \mathrm{hpf}$. R-cadherin message levels were al so high in the adult brain (Fig. 4). 


\begin{tabular}{|c|c|c|c|c|c|c|c|c|c|c|c|c|c|}
\hline & $\mathrm{zR}$ & $\mathrm{cR}$ & $\mathrm{hR}$ & $\mathrm{mR}$ & $\mathrm{XmN}$ & $\mathrm{zN}$ & $\mathrm{hN}$ & $\mathrm{xN}$ & $\mathrm{mN}$ & $\mathrm{mM}$ & h11 & $\mathrm{hP}$ & $\mathrm{hE}$ \\
\hline $\mathrm{zR}$ & & & & & & & & & & & & & \\
\hline $\mathrm{cR}$ & 77 & & & & & & & & & & & & \\
\hline $\mathrm{hR}$ & 76 & 92 & & & & & & & & & & & \\
\hline $\mathrm{mR}$ & 77 & 92 & 93 & & & & & & & & & & \\
\hline $\mathrm{XmN}$ & 71 & 81 & 78 & 78 & & & & & & & & & \\
\hline $\mathrm{zN}$ & 67 & 70 & 69 & 70 & 65 & & & & & & & & \\
\hline $\mathrm{hN}$ & 69 & 73 & 71 & 73 & 67 & 79 & & & & & & & \\
\hline $\mathrm{xN}$ & 66 & 70 & 68 & 70 & 64 & 76 & 84 & & & & & & \\
\hline $\mathrm{mN}$ & 68 & 73 & 70 & 73 & 66 & 78 & 98 & 82 & & & & & \\
\hline $\mathrm{mM}$ & 43 & 42 & 41 & 42 & 42 & 43 & 43 & 42 & 43 & & & & \\
\hline h11 & 39 & 41 & 40 & 40 & 39 & 40 & 41 & 41 & 41 & 33 & & & \\
\hline $\mathrm{hP}$ & 42 & 44 & 43 & 43 & 41 & 42 & 45 & 44 & 45 & 39 & 33 & & \\
\hline $\mathrm{hE}$ & 42 & 46 & 45 & 46 & 45 & 46 & 46 & 47 & 46 & 36 & 34 & 60 & \\
\hline
\end{tabular}

Fig. 2. Comparison of the putative zebrafish R-cadherin sequence with several other cadherin sequences. The table shows results of pairwise comparisons between various cadherin sequences: $z R$, putative zebrafish R-cadherin; $c R$, chicken R-cadherin; $h R$, human Rcadherin; mR, mouse R-cadherin; XmN, Xenopus R-cadherin; zN zebrafish $\mathrm{N}$-cadherin; hN, human $\mathrm{N}$-cadherin; $\mathrm{xN}$, Xenopus $\mathrm{N}$ cadherin; $\mathrm{mN}$, mouse $\mathrm{N}$-cadherin; mM, mouse M-cadherin; h11, human cadherin 11 ; hP, human P-cadherin; hE, human E-cadherin. Numbers given are percentage of amino acid identity for each comparison (made using Align X; I nformax Inc.). R-cadherin sequences, which include Xenopus $\mathrm{mN}$-cadherin, are highlighted (shaded). Diagonal black boxes indicate sequence comparisons between the same se quences, and therefore, represent $100 \%$ identity.

$33 \mathrm{hpf}, \mathrm{R}$-cadherin message was observed in the same general region, the ventronasal portion of the retina, but at this stage the retina had begun to laminate as inner retinal neurons had begun to differentiate, and the cluster of cells expressing R-cadherin was located in the innermost layers of the retina. The staining pattern did not change between $33 \mathrm{hpf}$ and $36 \mathrm{hpf}$ (Fig. 5A), but the intensity of labeling increased. By $50 \mathrm{hpf}$, the number of labeled cells had increased substantially (Fig. 5B), and these cells were seen in all four quadrants of the retina. By this stage, lamination was further advanced, and all the major retinal layers characteristic of the adult retina were visible in the ventronasal region. R-cadherin message remained confined to the inner layers of the retina, including the retinal ganglion cell layer and the inner nuclear layer, although the majority of cells expressing R-cadherin at this stage were located in the retinal ganglion cell layer (Fig. 6). Of those cells in the inner nuclear layer, the majority were in the innermost row, with only a few located in the second tier. Also at this stage, R-cadherin message was more abundant in the ventral two-thirds of the retina ( $F$ igs. 5B, 6C).

The staining pattern in the retina at $80 \mathrm{hpf}$ was similar to that at $50 \mathrm{hpf}$, in that R-cadherin message was detected in the inner portions of the retina, but there were more R-cadherin-positive cells in both the retinal ganglion cell layer and the inner nuclear layer, and these cells expressed higher levels of the message (Fig. 5C). The increase in the number of cells expressing R-cadherin was more obvious in the inner nucl ear layer than in the retinal ganglion cell layer. In the inner nuclear layer, many more labeled cells were found in the second and third tiers compared to embryos at $50 \mathrm{hpf}$ (Fig. 5C), although many were in the innermost row. R-cadherin expression was never observed in the outer nuclear layer, which contains the photoreceptor cell nuclei.

In retinas of 6-day larval zebrafish, expression of Rcadherin mRNA was greatly reduced, with only a few labeled cells scattered in the retinal ganglion cell and 


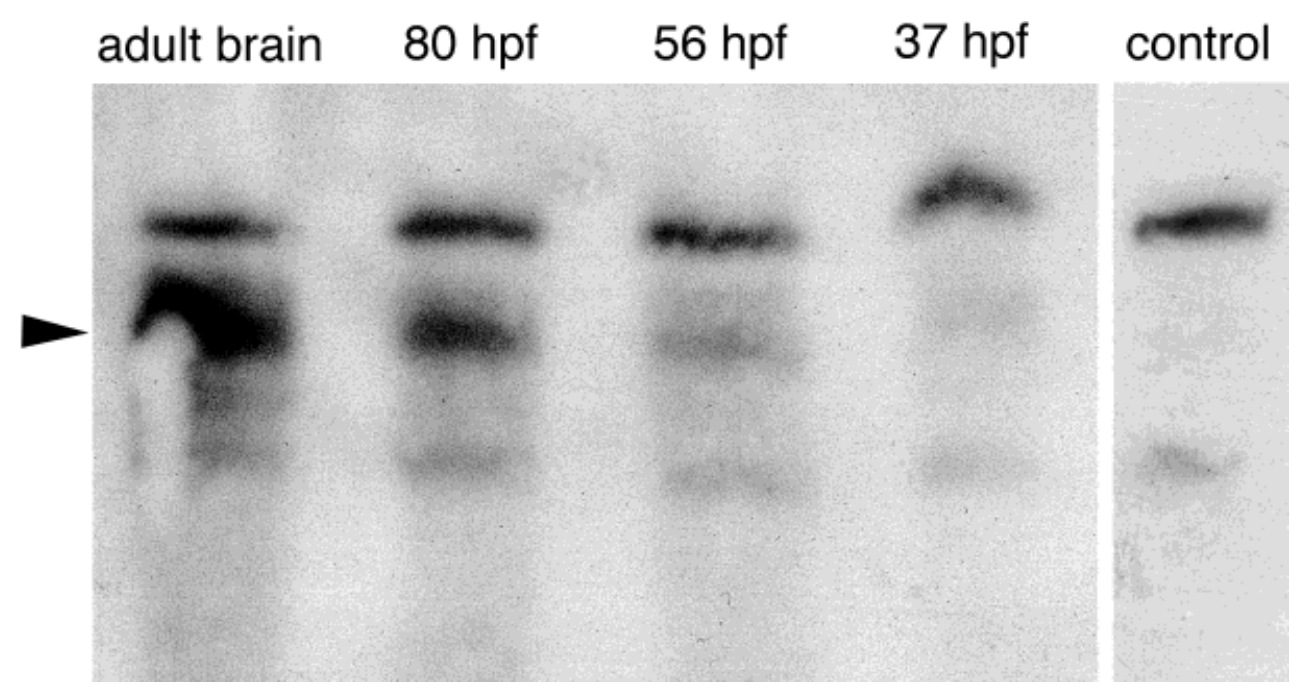

Fig. 4. RNase protection assay of zebrafish R-cadherin. Total RNA (15 $\mu \mathrm{g} / \mathrm{lane}$ ) from several stages of wholezebrafish embryos and brains of adult zebrafish were processed with a probe that protected a band of $437 \mathrm{bp}$ (arrowhead). Higher and lower bands present in all the lanes, including the control lane, represent an artifact from probe synthesis. The control lane contained the antisense probe without target RNA. Note the increased expression of R-cadherin message as the animal develops. hpf, hours postfertilization. inner nuclear layers (data not shown). This pattern was similar to that observed in the adult retina, where a few scattered cells in the retinal ganglion cell layer and the inner half of the inner nuclear layer expressed R-cadherin message (Fig. 5D). Generally, there were morelabeled cells in the inner nuclear layer than in the retinal ganglion cell layer in the adult. In addition to the retina, R-cadherin message was also seen in the lens of both embryos (Figs. 5B, 6C) and larval fish (Fig. 5C).

An earlier study in chicken showed that the optic nerve contained R-cadherin-positiveglial cells (Redies and Takeichi, 1993a). We therefore carefully examined the optic nerve in the retina of zebrafish embryos (50 hpf, Fig. 6C) and larvae (72-80 hpf, data not shown), but we found no R-cadherin expressing cells in the optic nerve.

Preparations with sense probes were negative. The specificity of the antisense probe for R-cadherin was verified as follows. First, the staining pattern using the longer probe (transcribed from the entire 1,982-bp insert of clone $9 \mathrm{cDNA}$ ) was compared to that of the shorter probe (transcribed using the 437-bp Bam HI fragment as a template). We found the same patterns in both embryos and larval fish, although the longer probe gave a stronger signal (data not shown). Second, we compared the pattern of expression of the R-cadherin probe with that of $\mathrm{N}$ cadherin at $50 \mathrm{hpf}$ (F ig. 6). As expected, $\mathrm{N}$-cadherin mRNA was detected throughout the zebrafish central nervous system in both undifferentiated and differentiated regions (Fig. 6B, D), whereas R-cadherin message was seen only in the differentiated regions, such as the retinal ganglion cell layer and the innermost portion of the inner nuclear layer (Fig. 6A, C). The proliferative, undifferentiated neuroepithelium at the retinal margins exhibited high levels of $\mathrm{N}$-cadherin message (Fig. 6D), but was negative for $\mathrm{R}$ cadherin (Fig. 6C). The staining patterns of $\mathrm{N}$ - and $\mathrm{R}$ cadherin in the brain were also different, particularly in regions of the pretectum and the optic tectum (F ig. 6A, B). From these results we infer that the R-cadherin probe did not cross-hybridize with the closely related $\mathrm{N}$-cadherin message.

\section{A subset of retinal ganglion cells express R-cadherin message}

In order to determine whether the R-cadherin-positive cells in the retinal ganglion cell layer were ganglion cells, we retrogradely labeled them with $\mathrm{Dil}$ at 57-60 hpf, and then processed cryosections for in situ hybridization using the R-cadherin cRNA probe. In some cases, the majority of cells in the retinal ganglion cell layer were labeled by Dil applied to the optic tectum and the pretectum (Fig. 7), and a subset of these Dil-labeled ganglion cells also contained R-cadherin message (Figs. 7, 8). Cells labeled for both Dil and R-cadherin were observed only in the retinal ganglion cell layer. We noted that processing the tissue for Dil caused some reduction in the intensity of the hybridization signal, and the number of cells expressing R-cadherin message in both the eye and brain was less than in larvae of the same stage that had not been processed for Dil .

\section{R-cadherin is expressed in the developing brain}

Regional boundaries and discrete brain nudei have not been defined or identified in early embryonic zebrafish brains. However, the early zebrafish brain is a relatively simple structure demarcated by a few major axonal tracts and small groups of differentiated cells (Chitnis and Kuwada, 1990; Wilson et al., 1990; Ross et al., 1992; Kimmel, 1993). Based on these landmarks, the earliest R-cadherin expression was located in the diencephalon, the pretectum, and the hindbrain. The term "pretectum" is used here to indicate the region of the brain immediately anterior and anteroventral to the presumptive optic tectum; this designation is in keeping with the general definition of the pretectum in adult teleost fish (Braford and Northcutt, 1983; Wullimann et al., 1996).

No hybridization signal was seen in embryos at $22 \mathrm{hpf}$; R-cadherin message was first seen at $24 \mathrm{hpf}$ in a small cluster of cells (4-6 on each side) in the presumptive pretectal area. The location of these cells was dorsal to the ventral flexure, at approximately one-third the distance 


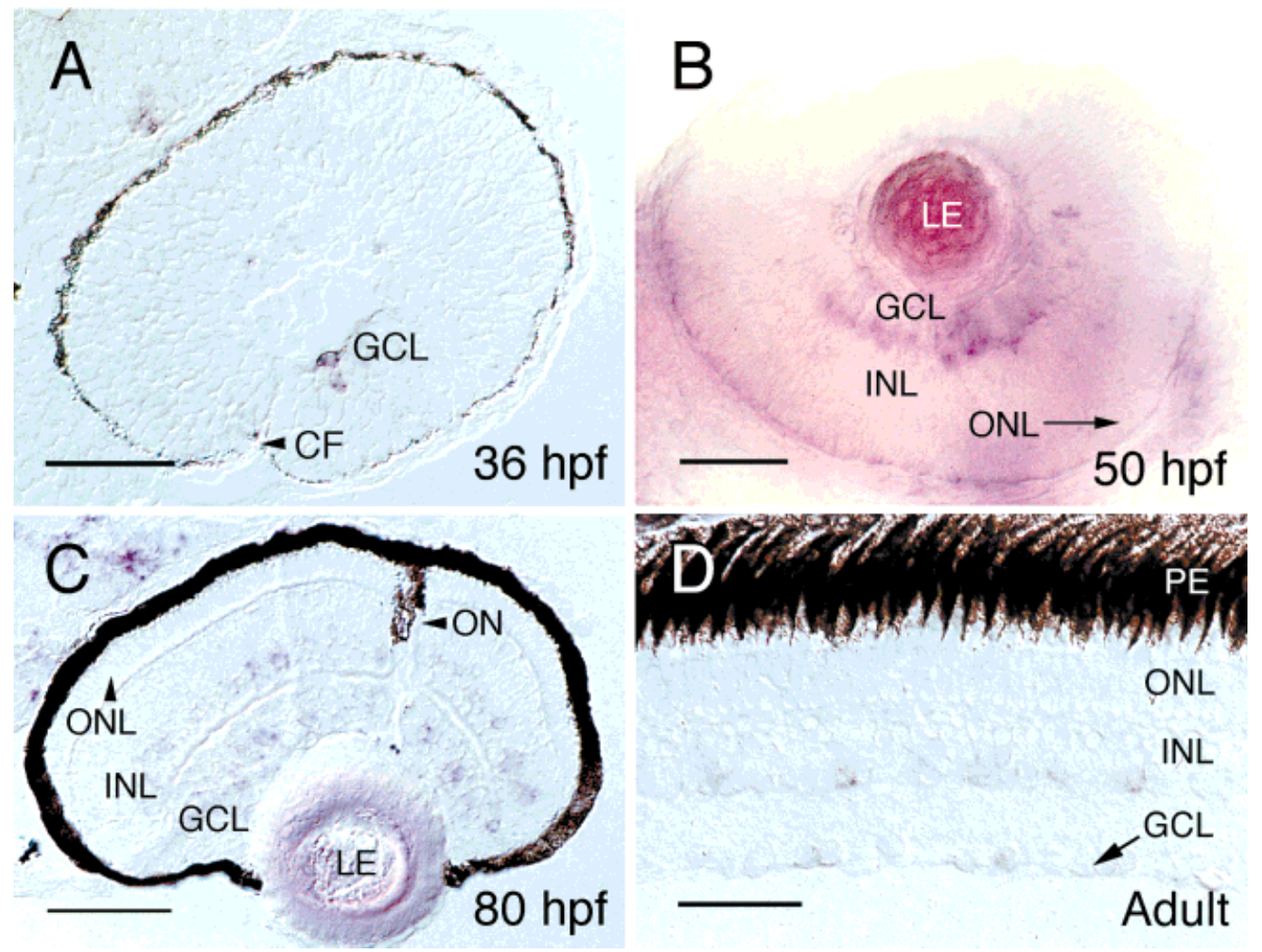

Figure 5

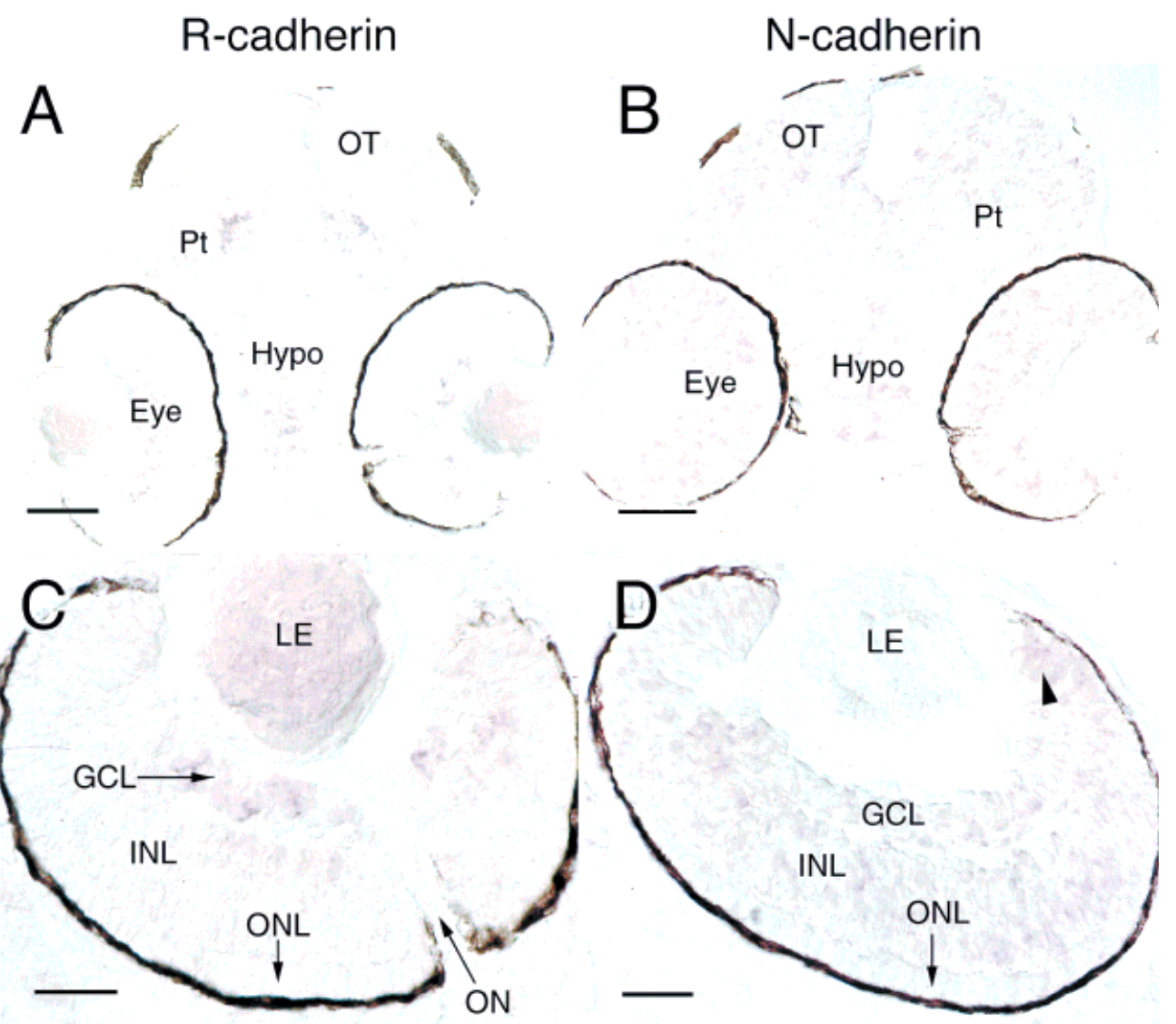


from the ventral to the dorsal surface of the brain. The expression pattern in this area remained the same between $24 \mathrm{hpf}$ and $29 \mathrm{hpf}$, except that at the later stage, the intensity of the signal increased (Fig. 9A). This cluster of cells was termed "R1" (Fig. 9).

In the diencephalon, R-cadherin mRNA was first detected at $25 \mathrm{hpf}$ in a presumptive hypothalamic region, here termed "R2." The R-cadherin staining pattern remained the same between 25 and $29 \mathrm{hpf}$, except that the labeling intensity increased (Fig. 9A). Viewed parasagittally, R2 was located immediately ventral to the optic recess (Fig. 9A). By 36 hpf (Fig. 10A), the number of cells and the intensity of the hybridization signal increased in the two areas expressing R-cadherin.

Cells expressing $\mathrm{R}$-cadherin message were also observed in the tel encephal on and the hindbrain. In the telencephaIon, R-cadherin mRNA was first seen at 28-29 hpf in a small cluster of cells in the dorsal region ("R3"; Fig. 9A). Cells expressing R-cadherin message in the hindbrain were first detected at $24 \mathrm{hpf}$ in the ventrolateral regions ("R4"; see bel ow).

By $40 \mathrm{hpf}$, the number of cells in the $\mathrm{R} 1$ region had further increased, mainly by addition of cells in the anterodorsal direction, so that R1 eventually approached the dorsal surface of the brain (Fig. 9B). The R-cadherin signal was particularly strong in two small clusters of cells near the dorsal surface (4-6 cells on each side). A few cells in the presumptive lateral thalamus (a region between R 1 and R2) also expressed R-cadherin message, but at lower levels (not shown). The labeling pattern of R2 was similar to that at earlier stages, except the size of R2 had increased, mainly by addition of cells in the caudoventral direction. R-cadherin expression pattern remained the same in the telencephalon. In the hindbrain, there was a significant increase in the number of cells expressing

Fig. 5. In situ hybridization showing R-cadherin expression in the zebrafish retina. A, C, and D are cryosections; $B$ is a wholemount preparation. A: At 36 hours postfertilization (hpf), R-cadherin antisense probe hybridization signal was confined to a small patch of cells in the ganglion cell layer (GCL) near the choroid fissure (CF) in the ventronasal portion of the retina. B: Lateral view of the eye of a zebrafish embryo (50 hpf). In the retina, R-cadherin message was confined to the ganglion cell layer and the innermost portion of the inner nuclear layer (I NL). Morelabel ed cells were in the ventral half of the retina than in the dorsal half. The outer nuclear layer (ONL) is indicated by the arrow. Nasal (anterior) is to the right and dorsal is at the top. LE, lens. C: At 80 hpf, many more cells contain R-cadherin message, but they remain confined to the retinal ganglion cell layer and inner nuclear layer. R-cadherin mRNA is also found in the lens of both the younger (B) and older (C) eyes. ON, optic nerve. D: In adult zebrafish retina, the hybridization signal was located in a few cells scattered in the GCL and along the inner part of the inner nuclear layer. PE, pigmented epithelium. Scale bars $=40 \mu \mathrm{m}$ for A and D; 50 $\mu \mathrm{m}$ for $\mathrm{B}$ and $\mathrm{C}$.

Fig. 6. Expression patterns of R-cadherin (left) and N-cadherin (right) in the brain and eye of embryos at 50 hours postfertilization (hpf). A and $\mathbf{B}$ are adjacent cross-sections from the same animal at mid-mesencephalic level. Dorsal is at the top. In the brain, expression of R-cadherin (A) is restricted to localized regions, compared to $\mathrm{N}$-cadherin (B) which is more widely expressed. $\mathbf{C}$ and $\mathbf{D}$ are higher magnifications of eyes labeled with $\mathrm{R}$ - and $\mathrm{N}$-cadherin CRNA probes, respectively. $C$ is a higher magnification of the right eye in $A$, and $D$ is from another section. The arrowhead in $\mathrm{D}$ points to $\mathrm{N}$-cadherin message in the proliferating germinal zone at the retinal margin. Hypo, hypothalamus; OT, optic tectum; Pt, pretectum. Other abbreviations as in Figure 5. Scale bars $=50 \mu \mathrm{m}$ for $A$ and $B ; 25 \mu \mathrm{m}$ for $C$ and D.
R-cadherin (Fig. 9B). These cells (R4) were still confined to the ventrolateral hindbrain regions.

At 50 hpf, many more cells expressed R-cadherin mRNA, and the signal intensity was increased (Figs. 9C, 10B). By this stage, cells expressing R-cadherin were located throughout the diencephalon, linking the areas designated R1 and R2 at earlier stages. The R3 cluster in the telencephalon had also increased in size by addition of cells in the ventral direction (Fig. 9C). There were also more R-cadherin-expressing cells in the hindbrain (R4), but the expression pattern was similar to that at $40 \mathrm{hpf}$. By $80 \mathrm{hpf}, \mathrm{R}$-cadherin message was detected in groups of cells scattered throughout the diencephalon, the pretectum, and the hindbrain, and the overall signal intensity was stronger than at $50 \mathrm{hpf}$ (Fig. 11B).

In 6-day-old larvae, expression of R-cadherin message was greatly reduced (data not shown).

\section{$\mathbf{R}$-cadherin expression begins in the anterior optic tectum and moves posterior during development}

Unlike the well-laminated adult optic tectum, the optic tectum of early zebrafish embryos is a uniform, densely packed, layer of undifferentiated neuroepithelial cells. $\mathrm{R}$-cadherin mRNA was first detected at $40 \mathrm{hpf}$ (data not shown); at this stage the hybridization signal was weak and confined to a few cells in the anterolateral portion of the tectum, just dorsal to R1 in the pretectum. By $50 \mathrm{hpf}$, the number and intensity of cells expressing R-cadherin in this region had increased (Fig. 11A, C). Although cells expressing low levels of R-cadherin message were scattered in the anterior and middle portions of the tectum, the most intense cells were found in the anterolateral tectum adjacent to $\mathrm{R} 1$.

By $80 \mathrm{hpf}$, the optic tectum had developed into a two-layered structure: a superficial fibrous layer, which was most evident in the lateral two-thirds of the tectum, and a deeper layer where most of the cell bodies reside. At this time, the number of cells expressing high levels of R-cadherin message had increased over that seen in embryos at $50 \mathrm{hpf}$, and R-cadherin-positive cells were found throughout the cellular layer (Fig. 11B, D). Rcadherin expression was greatly reduced in the tectum of 6-day larval fish, which had a similar pattern of labeling to that seen in the adult (described below).

\section{$\mathbf{R}$-cadherin expression is maintained in restricted subsets of neurons in the adult zebrafish}

Identification of adult zebrafish brain structures and their nomenclature is according to a zebrafish brain atlas (Wullimann et al., 1996).

Because R-cadherin was first observed in several regions that are potentially visual structures in developing zebrafish, we wondered whether R-cadherin was present in retinal recipient areas in adult zebrafish (Wullimann and Meyer, 1990; Rupp and Wullimann, 1996). In situ hybridization using the R-cadherin probe showed Rcadherin message in most of the known brain targets of the retinal ganglion cells, including the optic tectum (Fig. $12 \mathrm{~A}-\mathrm{C}, \mathrm{H}$ ), the accessory pretectal nucleus (Fig. 12C), the anterior thalamic nucleus (Fig. 12E), the parvocellular superficial pretectal nucleus (Fig. 12D), the posterior pretectal nucleus (Fig. 12C), and the ventrolateral thalamic nucleus (Fig. 12E). Other structures not shown, 

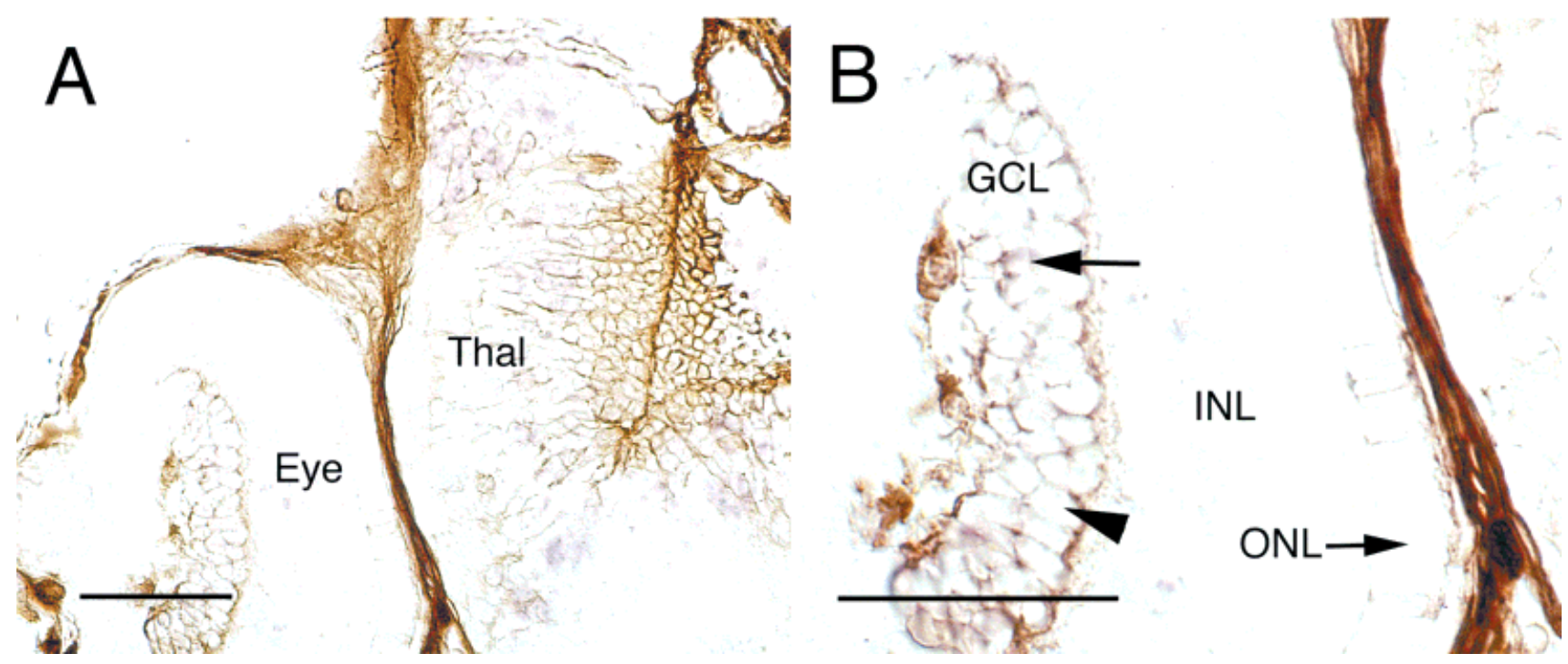

Fig. 7. Retrograde labeling of retinal ganglion cells by injection of 1,1'-dioctadecyl-3,3,3',3', tetramethylindocarbocyanine perchlorate (Dil) into the optic tectum and the pretectum of larvae at 57-60 hours postfertilization (hpf). A: Cross-section through the pretectal region showing part of the Dil-injected thalamus (Thal) and retinal cells that were labeled by retrograde transport of Dil. Dorsal is at the top, and lateral is to the left. Due to spread of Dil solution, the surfaces of the brain and eyes were usually labeled, as were many cells and fiber tracts in the brain near the injection site. B: Higher magnification of

the eye in A. Most of the cells in the retinal ganglion cell layer (GCL) were completely or partially outlined by brownish Dil-reaction product. R-cadherin signal is blue or purple. The arrowhead indicates a Dil-labeled ganglion cell that did not contain R-cadherin message, whereas the arrow points to a ganglion cell that was double-labeled with Dil and R-cadherin mRNA. Due to leakage of Dil across the back of the eye, a few immature photoreceptor cells in the outer nuclear layer (ONL) are weakly outlined by Dil label. INL, inner nuclear layer. Scale bars $=50 \mu \mathrm{m}$.

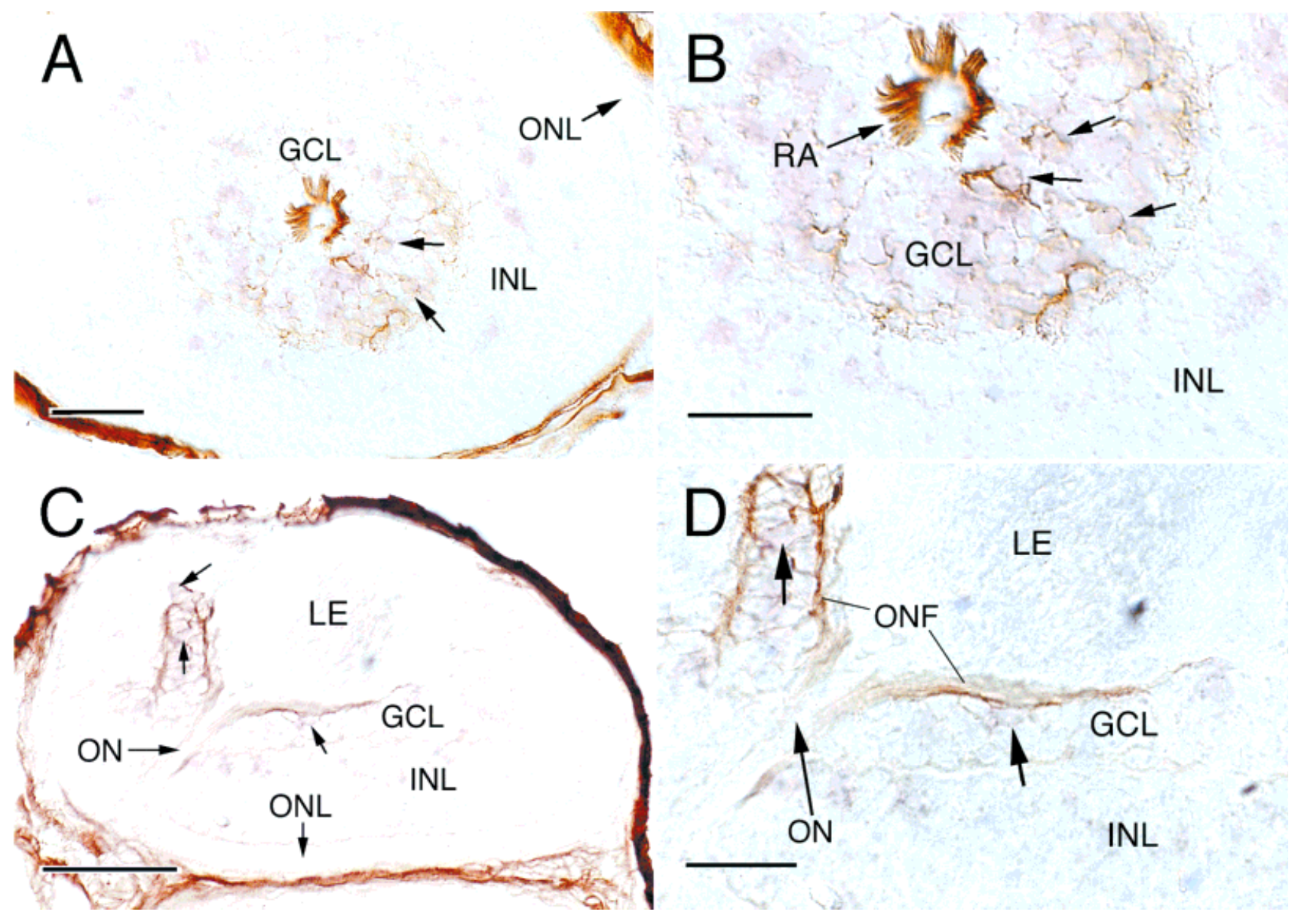

Figure 8 
including the central pretectal nudeus, the dorsal accessory optic nucleus, the intermediate thalamic nucleus, the periventricular pretectal nucleus, and the suprachiasmatic nucleus in the anterior hypothalamus, all contained $\mathrm{R}$-cadherin mRNA. The only retinal recipient nucleus in which we did not detect R-cadherin message was the ventrolateral thalamic nucleus.

In the optic tectum, cells expressing R-cadherin were largely confined tolayer 3 of the periventricular gray zone. Although signal was detected in many cells throughout this layer, intensely R-cadherin-positive cells were found mainly in the upper half (Fig. $12 \mathrm{H}$ ), with more in the anterior and posterior regions than in the middle region of the tectum (data not shown).

The above results suggest that R-cadherin may play a role in the function and/or maintenance of the visual system. This idea is supported by our finding that Rcadherin message was also expressed in brain regions that are known to be connected with the optic tectum, the main target of the retinal ganglion cells (Braford and N orthcutt, 1983; Striedter and Northcutt, 1989; Rupp and Wullimann, 1996). These regions included the central posterior thalamic nucleus (Fig. 12G), the dorsal posterior thalamic nucleus (data not shown), the magnocellular superficial pretectal nucleus (data not shown), and the nucleus isthmi (Fig. 12F).

Finally, cells expressing R-cadherin were found in the hypothalamus, and small numbers of cells in other brain regions in the telencephalon, the midbrain tegmentum and the medulla also expressed R-cadherin (data not shown). A detailed study of R-cadherin expression in these structures will be reported later.

\section{DISCUSSION \\ Isolation of a cadherin molecule that is most homologous to R-cadherin}

Two cDNA clones that encode a member of the cadherin superfamily were obtained by screening zebrafish cDNA libraries by using an antibody to the conserved cadherin cytoplasmic domain. Amino acid sequence comparisons of this fish cadherin molecule with various cadherin molecules from other vertebrate species revealed that it had the highest identity with mouse, chicken, human, and Xenopus R-cadherin. This information, together with its expression pattern in developing zebrafish, strongly suggests that these cDNAs represent partial clones of a

Fig. 8. R-cadherin expression in 1,1'-dioctadecyl-3,3,3',3', tetramethylindocarbocyanine perchlorate (Dil)-labeled retinal ganglion cells. A is from one animal and $\mathbf{C}$ is from another. $\mathbf{B}$ and $\mathbf{D}$ are higher magnifications of parts of $A$ and $C$, respectively. $A$ is a sagittal (en face) section of the eye. Unlabeled arrows indicate Dil -label ed ganglion cells that were also R-cadherin-positive (double-labeled cells). Bundles of Dil-label ed retinal axons (RA) were seen in the central area, surrounding the lens. Dorsal is at the top and anterior is to the left. C: Cross-section of an eye. Dorsal is to the right and lateral is at the top. Note that there are no weakly labeled photoreceptors in the outer nuclear layer, indicating that the Dil did not penetrate through the back of the eye in this preparation as it did in the eye illustrated in Figure 7. Unlabeled arrows point to some double-labeled cells in the ganglion cell layer which are shown at a higher magnification in $\mathrm{B}$ and D. IPL, inner plexiform layer; ONF, optic nerve fiber layer. Other abbreviations as in Figure 5. Scale bars $=25 \mu \mathrm{m}$ for A and C; $20 \mu \mathrm{m}$ for $\mathrm{B}$ and $\mathrm{D}$.

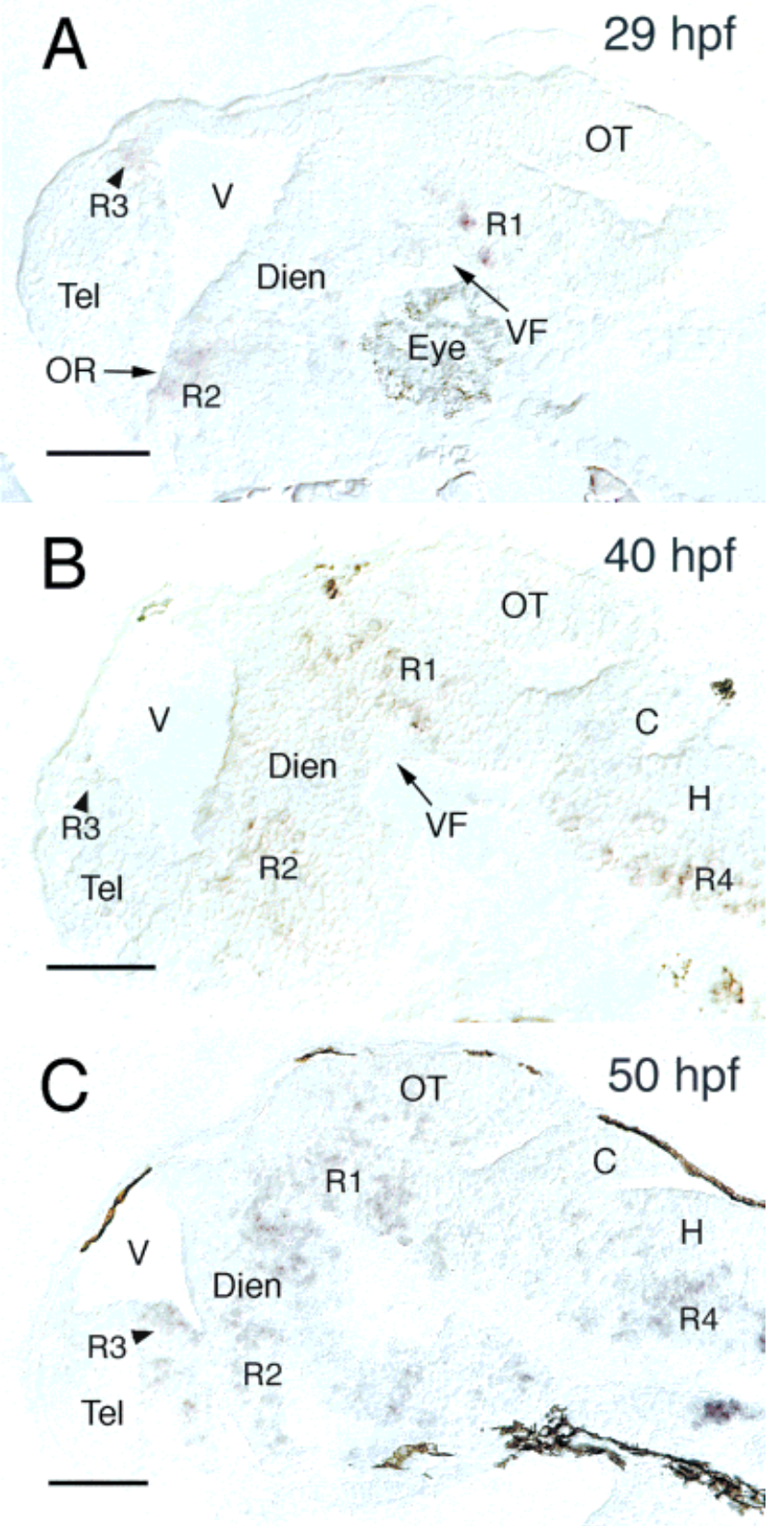

Fig. 9. Photomicrographs of parasagittal sections of embryonic zebrafish brain demonstrating R-cadherin expression. Anterior is to the left and dorsal is at the top in all panels. A: At 29 hours postfertilization (hpf), cells expressing R-cadherin were located in the pretectum (R1), the hypothalamic region (R2), the dorsocaudal telencephalon (R3), and the hindbrain (not shown in this picture due to the angle of the section). A fragment of the left eye, which has been displaced during histological sectioning, is indicated. B: At $40 \mathrm{hpf}$, cells in R1 and R2 that expressed R-cadherin mRNA were more numerous. Other pretectal areas anterodorsal to R1 also contained labeled cells. The number of cells expressing R-cadherin message in the hindbrain (R4) had greatly increased. C: Both the number of cells expressing R-cadherin and the intensity of the signal increased in the brain of $50 \mathrm{hpf}$ embryos. Labeled cells were no longer confined to discrete regions (e.g., R1 and R2). C, cerebellum; Dien, diencephalon; $\mathrm{H}$, hindbrain; OR, optic recess; OT, optic tectum; Tel, telencephal on; V, ventricle; VF, ventral flexure. Scale bars $=50 \mu \mathrm{m}$ 

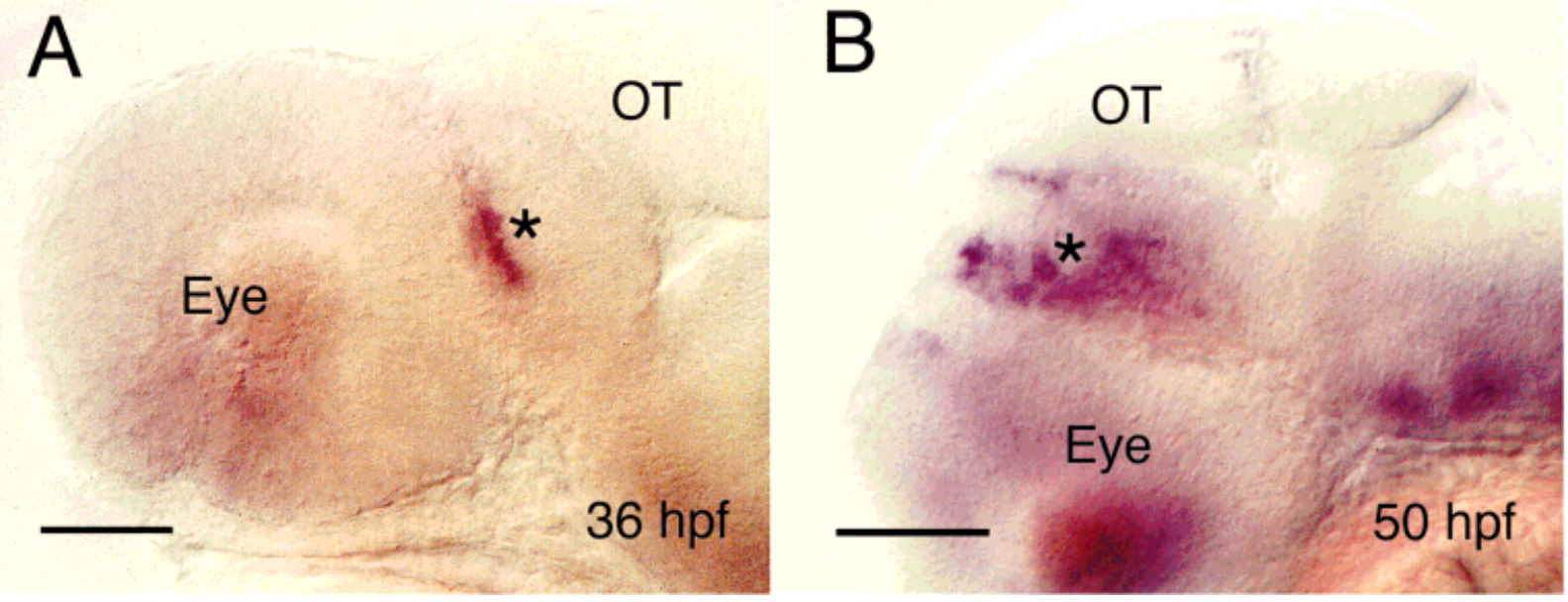

Fig. 10. Photomicrographs of wholemount zebrafish embryos at 36 and 50 hours postfertilization (hpf) showing hybridization of R-cadherin CRNA in the pretectal region (R1). A:At $36 \mathrm{hpf}$, a small cluster of cells expressing R-cadherin (asterisk) was found in the region designated as R1. B: At $50 \mathrm{hpf}$, the number of R-cadherin expressing cells (asterisk) in R 1 was greatly increased and R-cadherin expression had spread to other brain regions. OT, optic tectum. Scale bars $=50 \mu \mathrm{m}$.

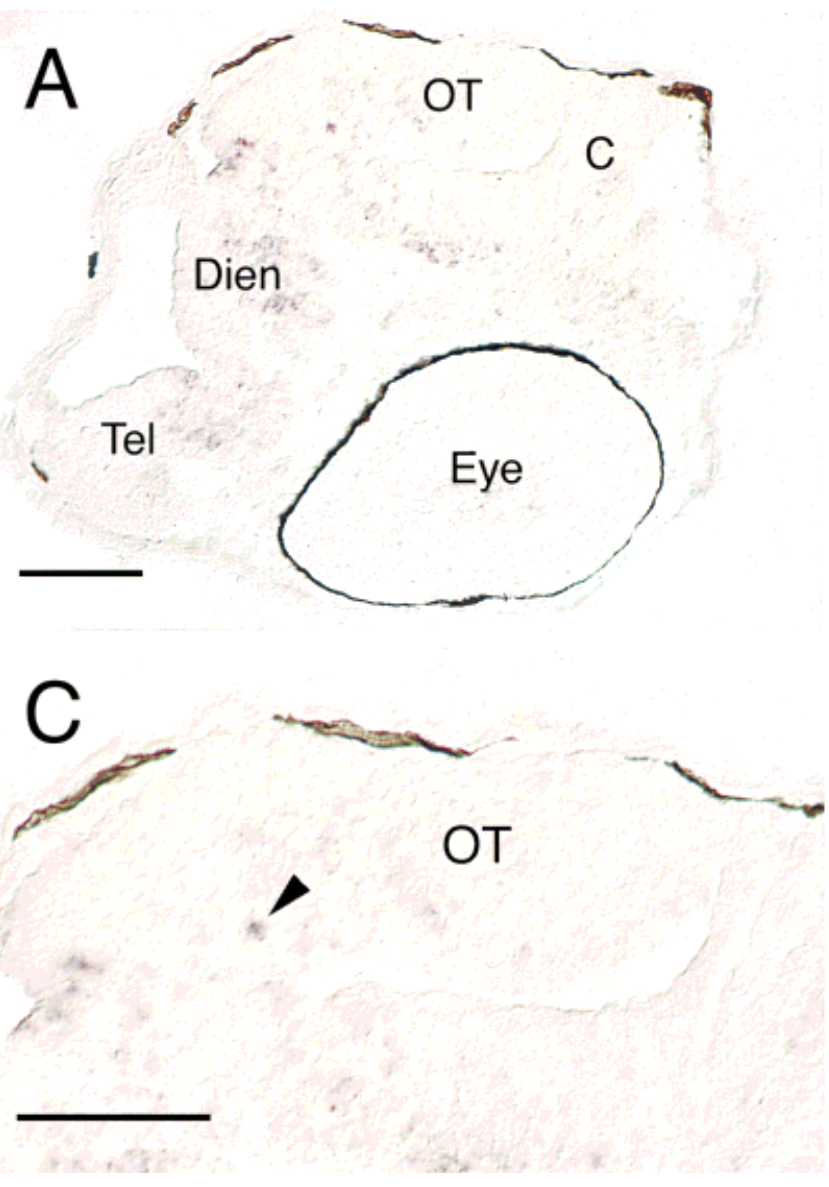

Fig. 11. R-cadherin expression in the optic tectum (OT) of embryonic brain (parasagittal sections). C and $\mathbf{D}$ are higher magnification images of $\mathbf{A}$ and $\mathbf{B}$, respectively. In embryos at 50 hours postfertilization (hpf; A and C), cells expressing R-cadherin mRNA were seen in the anterior and middle portions of the optic tectum; intensely labeled tectal cells (arrowhead in C) were only found in the anterior one-third

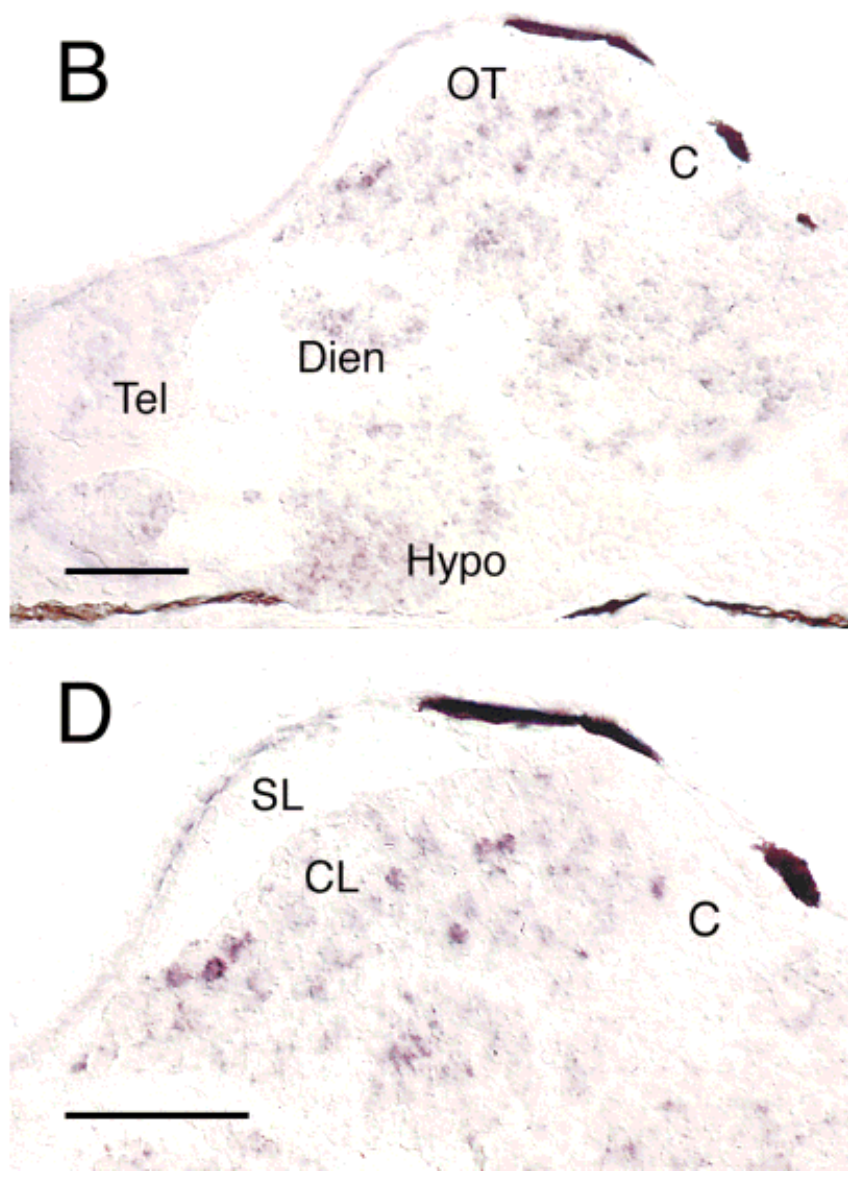

of the tectum. At $80 \mathrm{hpf}$ ( $\mathrm{B}$ and $\mathrm{D}$ ), R-cadherin message was detected throughout the cellular layer (CL) of the OT. R-cadherin was also expressed widely in the brain (except the presumptive cerebellum) at this stage. Anterior is to the left and dorsal is at the top for all figures. $\mathrm{SL}$, superficial layers of the tectum. Other abbreviations as in Figures 6 and 9 . Scale bars $=50 \mu \mathrm{m}$ 
zebrafish R-cadherin orthologue. Efforts are underway to isol ate a complete cDNA clone.

\section{$\mathbf{R}$-cadherin expression is developmentally regulated in zebrafish retina and brain}

The earliest stage that the putative zebrafish Rcadherin could be detected by in situ hybridization was 24 hpf, a time when the earliest neuronal progenitors and the major axonal tracts have already developed (Chitnis and Kuwada, 1990; Ross et al., 1992). We did not use more sensitive methods, such as reverse transcriptase-polymerase chain reaction (RT-PCR), to determine when Rcadherin message is first expressed, although we presume that it must be earlier than $24 \mathrm{hpf}$, because we were ableto isolate a cDNA clone from a 15- to 19-hour zebrafish embryo library. Both the in situ hybridization and the RNase protection studies demonstrated that the levels of $\mathrm{R}$-cadherin increase as neuronal differentiation proceeds in the embryonic zebrafish brain and retina, similar to what has been shown in embryonic chicken (I nuzuka et al., 1991) and mouse (Matsunami and Takeichi, 1995). In contrast, $\mathrm{N}$-cadherin is strongly expressed in undifferentiated neuroepithelial cells in zebrafish (Bitzur et al., 1994; present study) as it is in other species (Hatta et al., 1987; Redies and Takeichi, 1996).

\section{$\mathbf{R}$-cadherin is expressed by differentiated retinal ganglion cells}

The onset of expression of R-cadherin in the zebrafish retina approximately corresponds to the stage when retinal ganglion cells begin to differentiate and extend their axons. Retinal ganglion cells start to become postmitotic around 28 hpf (Nawrocki, 1985; Hu and Easter, 1999), and the first axons have reached the optic chiasm by $32 \mathrm{hpf}$ (Stuermer, 1988; Burrill and Easter, 1995). The first gangl ion cells to differentiateare clustered in the ventronasal region of the retina near the optic fissure (Burrill and Easter, 1995; Laessing and Stuermer; 1996; Schmitt and Dowling, 1996), and this is al so the area where the earliest cells that express R-cadherin were observed.

Progenitors of retinal ganglion cells become postmitotic at the ventricular (outer) surface of the retina, then migrate to the inner surface (Nawrocki, 1985; M CLoon and Barnes, 1989; Hu and Easter, 1999). The first cells to express R-cadherin in the retina were transiently located at the outer surface of the ventronasal retina, consistent with the suggestion that at least some retinal ganglion cells begin to express R-cadherin soon after they become postmitotic. In the retinas of older embryos and larvae, cells expressing R-cadherin were confined to areas occupied mainly by differentiated cells in the inner retinal layers.

By $50 \mathrm{hpf}$, retinal ganglion cells are differentiating throughout the entire embryonic zebrafish retina, but they are more mature (and more numerous) in the ventral two-thirds of the retina (Burrill and Easter, 1995; Schmitt and Dowling, 1996). At this stage, we found an increase in number of cells in the retinal ganglion cell layer that expressed R-cadherin mRNA, especially in the ventral retina.

The identity of R-cadherin-positive cells in the ganglion cell layer was determined by backfilling retinal ganglion cells with Dil. We chose the stages of development between 57 and $60 \mathrm{hpf}$ for these experiments because, first, in embryos younger than $48 \mathrm{hpf}$, the majority of retinal axons have not reached the optic tectum (Stuermer, 1988; B urrill and Easter, 1994), the most accessible location for Dil placement. Second, the hybridization signal for R-cadherin message in the retina of embryos younger than 57 hpf was relatively weak compared to that in older fish, and the signal usually became weaker after Dil transport and photoconversion. We found many examples of Dil-labeled, R-cadherin-positive cells in the retinal ganglion cell layer, and we conclude that these are ganglion cells. In this respect, zebrafish apparently differs from both chicken and mouse, in which retinal ganglion cells have not been reported to express $\mathrm{R}$-cadherin, but instead express $\mathrm{N}$ cadherin (Inuzuka et al., 1991; Redies and Takeichi, 1993a; Wohrn et al., 1998). Cells in the retinal ganglion cell layer of embryonic and adult zebrafish also express $\mathrm{N}$-cadherin message (P.A. Raymond and L.K. Barthel, unpublished observation), but it is not known whether individual ganglion cells express both $\mathrm{N}$ - and R-cadherin. Colocalization of different cadherins (cadherin-6B and cadherin-7) has been recently shown in retinal cells, including ganglion cells, in chicken retina (Wohrn et al., 1998).

As embryonic retinal development proceeded, more cells in the ganglion cell layer expressed R-cadherin, but in the retinas of 6-day-old larvae, as well as in adults, message was detected only in a few scattered cells. Therefore, the peak of R-cadherin expression was closely correlated with stages in which differentiation and maturation of retinal ganglion cells take place in the zebrafish embryo, suggesting that this molecule might be involved in their development. After differentiation, R-cadherin expression persisted in a subset of retinal ganglion cells.

R-cadherin hybridization signal was also observed in cells in the inner portion of the inner nuclear layer. Although their identity has not been determined, their location suggests that they are amacrine cells. It is possible that some of these cells are displaced retinal ganglion cells, but not all of them could be, because there are very few displaced retinal ganglion cells in the zebrafish embryo at these embryonic stages (Burrill and E aster, 1995). Some of the R-cadherin-expressing cells located in the middle strata of the inner nuclear layer may also be either bipolar cells or Müller cells. R-cadherin-positive bipolar cells and Müller cells have been described in chicken retina (I nuzuka et al., 1991; Wohrn et al., 1998).

Soon after extending axonal processes, retinal ganglion cells begin to grow dendrites that project into the developing inner plexiform layer (Burrill and E aster, 1995), where they synapse with amacrine cells. It is possible that homophilic cell adhesion mediated by R-cadherin expressed on both pre and postsynaptic neurons may play a role in establishing synaptic connections within the zebrafish retina, as has been suggested in the chicken brain (Redies et al., 1992, 1993; Redies, 1995, 1997).

In chicken (Inuzuka et al., 1991; Liu et al., 1997), immunostaining revealed that $\mathrm{R}$-cadherin protein first appeared in the neural retina at embryonic day 8 (E8; Inuzuka et al., 1991). Staining was found in the plexiform layers (outer and inner), the inner nuclear layer, and the ganglion cell layer, although the identity of the cells that expressed R-cadherin is not known. As the retina developed, immunoreactivity first increased from E 10 to E 14, then decreased at around hatching. R-cadherin immunoreactivity was strongest in these layers at a time when retinal ganglion cells are extending their axons toward 

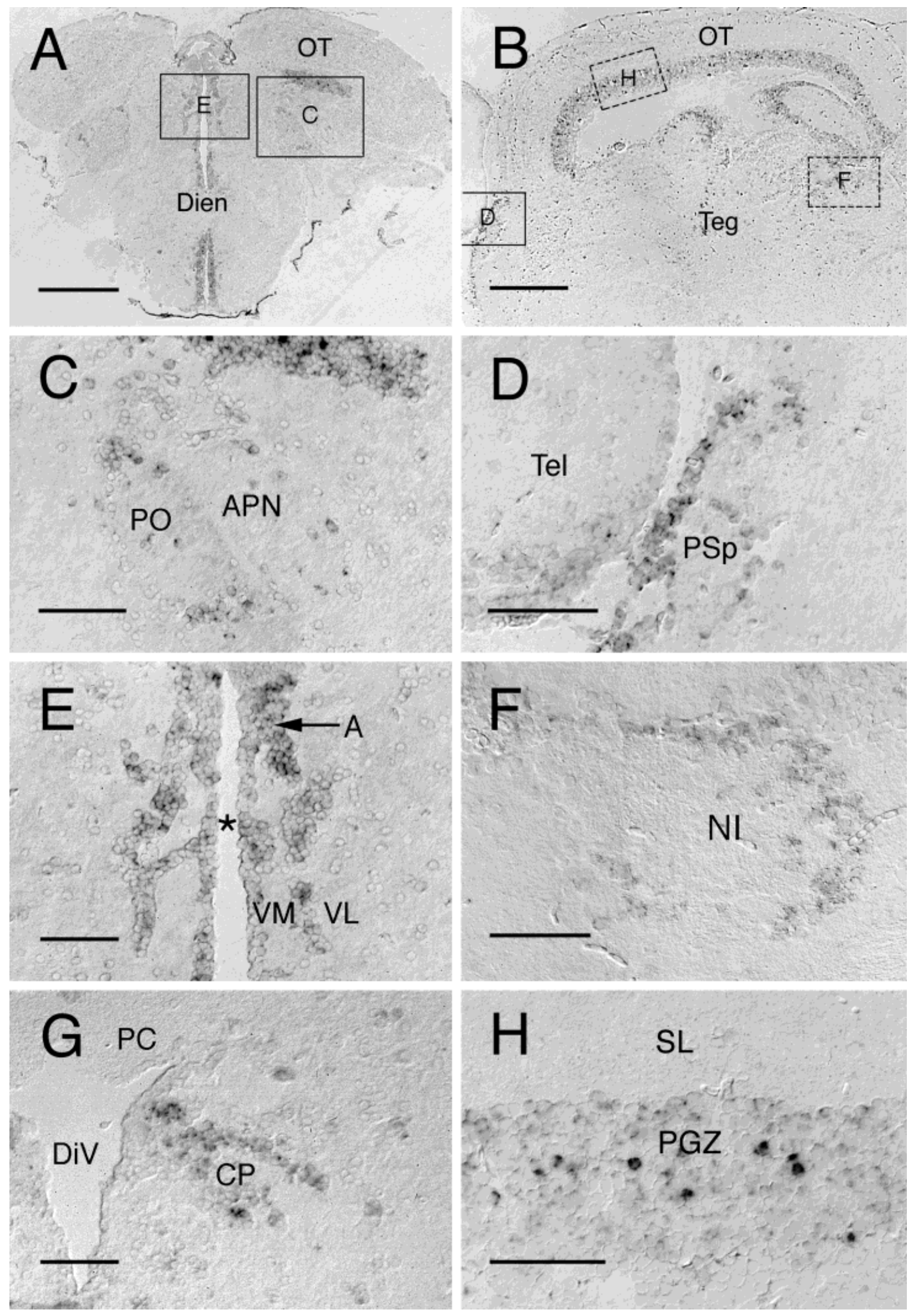

Figure 12 
their central targets in the brain, and their dendrites are making synaptic contacts in the inner plexiform layer of the retina (Del ong and Coulombre, 1965; Goldberg, 1974; Halfter et al., 1985; I nuzuka et al., 1991). However, in the chick embryo, the retinal ganglion cell axons were not immunoreactive for R-cadherin, and R-cadherin-positive elements in the optic nerve were shown to be glial cells (Redies and Takeichi, 1993a). In contrast, we did not observe any glial cells in the zebrafish optic nerve that expressed R-cadherin message. We cannot explain this discrepancy in the expression of R-cadherin message between zebrafish and chicken, other than to invoke species differences. This is discussed further in the companion paper (Liu et al., 1999).

\section{R-cadherin expression in the zebrafish visual system}

The earliest differentiated neurons in the developing zebrafish brain, identified by the neuronal differentiation marker acetylchol inesterase, are located in three clusters: the dorsorostral (dorsoanterior), ventrorostral (ventroanterior), and ventrocaudal (ventroposterior) clusters (Ross et al., 1992). These clusters give rise to neurons in the telencephal on, ventral diencephalon, and mesencephalic tegmentum, respectively. M ost of the earliest R-cadherinpositive cells in embryonic zebrafish brain can be assigned to these previously identified clusters. The R-cadherinexpressing cluster $\mathrm{R} 1$ appears to be in the dorsal portion of the ventrocaudal cluster, an area occupied by the lateral tegmental cluster and the nucleus of the posterior commissure (Chitnis and Kuwada, 1990). The pretectal area in both embryonic fish (Burrill and Easter, 1994) and adult fish (Braford and Northcutt, 1983; Striedter and Northcutt, 1989; Rupp and Wullimann, 1996) receives extensive retinal projections, so it is highly likely that RI is a terminal field of retinal ganglion cell axons.

R2 appears to be located within the ventrorostral cluster (Ross et al., 1992), i.e., the nucleus of the tract of the postoptic commissure (Chitnis and Kuwada, 1990). Cells expressing R-cadherin message in the telencephal on (R3) seem to be located within the dorsorostral cluster. Although R-cadherin-containing cells in the region of the optic recess in the chicken diencephal on have been identified as glial cells (Gänzler and Redies, 1995), in the present study the location of R2 and the size of the somata support the idea that cells expressing R-cadherin in the corresponding area in zebrafish brain are differentiated neurons. This inference is also supported by our finding that there were no R-cadherin-positive glial cells in the optic nerve. In embryonic zebrafish spinal cord, postmitotic neurons are located in lateral positions, whereas mitotically active neuroepithelial cells occupy the central region (Bernhardt et al., 1990; Kuwada et al., 1990). Cells expressing R- cadherin message in the spinal cord of embryonic zebrafish (24-50 hpf) are seen only in the lateral region (Liu and Raymond, unpublished observations), providing additional supporting evidence that R-cadherin mRNA is expressed by postmitotic neurons.

The developmental profile of R-cadherin expression in the pretectum and optic tectum in zebrafish embryos correlated closely with the known timing of axonal outgrowth of retinal ganglion cells (Stuermer, 1988; Burrill and Easter, 1994, 1995). Cells in the presumptive terminal fields in the pretectum (R1) and the optic tectum all began to express R-cadherin prior to the arrival of the retinal axons, and expression levels were greatly increased during the period when retinal axons were arborizing within their targets (Stuermer, 1988; Kaethner and Stuermer, 1992; Burrill and Easter, 1994, 1995). For example, in the optic tectum, R-cadherin expression was first detected around $40 \mathrm{hpf}$, whereas the retinal axons reach the tectum at about $44 \mathrm{hpf}$, and arborize extensively between 52 and 80 hpf (Stuermer, 1988; Kaethner and Stuermer, 1992; Stuermer et al., 1990; Burrill and Easter, 1994). Between 40 and $52 \mathrm{hpf}, \mathrm{R}$-cadherin expression was restricted to the anterolateral area of the tectum, during which time the retinal axons are beginning to terminate only in these areas (Stuermer, 1988; Burrill and Easter, 1994). By 80 $\mathrm{hpf}$, when R-cadherin expression was found throughout the cellular layer of the tectum, the retinal axons have covered the entire tectal area (Stuermer, 1988; Burrill and Easter, 1994).

In general, the expression levels of R-cadherin message were reduced in the brain of 6-day larvae, when the visual system is already well devel oped (Stuermer, 1988; Burrill and Easter, 1994; Easter and Nicola, 1996). This developmental profile of zebrafish R-cadherin is similar to that of $\mathrm{N}$ - and $\mathrm{R}$-cadherins in chicken, where expression is upregulated as neurons differentiate and send out their processes, then becomes most prominent during active neurite growth and synaptogensis, and is significantly reduced thereafter (reviewed by Redies, 1997). It has been suggested that cadherin-mediated adhesive interactions play a role in generating specificity of neuronal connections in chicken (Redies et al., 1992, 1993). The observations reported here suggest that R-cadherin might similarly be involved in formation of visual circuits in zebrafish. In the retina, optic tectum, and most retinal recipient areas in the brain of adult zebrafish, strong expression levels were maintained in a few cells, suggesting that R-cadherin may also have a role in maintenance of the functioning visual system.

The distribution of R-cadherin in the visual structures of the developing chicken brain has been studied previously (Gänzler and Redies, 1995; Arndt and Redies, 1996). Similar to the zebrafish brain, R-cadherin expression in
Fig. 12. Cross-sections (left column) and sagittal sections (right column) of adult zebrafish brain showing expression of R-cadherin message in visual structures. A: Cross-section of diencephalic and mesencephalic regions. B: Sagittal section of the mesencephalic region (anterior is to the left and dorsal is at the top). Boxed areas in A and B contain cells expressing R-cadherin mRNA shown at higher magnification in panels as indicated. Boxes with dashed lines indicate the corresponding areas for the photographs at higher magnification (F and $\mathbf{H}$ ), that were taken from adjacent sections. Retinal recipient structures are shown in $\mathbf{C - E}$ and $\mathrm{H}$; visual structures that have reciprocal connections with the optic tectum are shown in $\mathrm{F}$ and $\mathbf{G}$.
The latter $(G)$ is from a section that was posterior to the level of the cross-section shown in A. A, anterior thalamic nucleus; APN, accessory pretectal nucleus; $\mathrm{CP}$, central posterior thalamic nucleus; DiV, diencephalic ventricle; NI, nucleus isthmi; PC, posterior commissure; PGZ, periventricular gray zone of the optic tectum; PO, posterior pretectal nucleus; PSp, parvocellular superficial pretectal nucleus; SL, superficial layers of the tectum; Teg, tegmentum; VL, ventrolateral thalamic nucleus; VM, ventromedial thalamic nucleus. Other abbreviations as in Figure 9. Asterisk in $\mathrm{E}$ indicates the diencephalic ventricle. Scale bars $=250 \mu \mathrm{m}$ for $\mathrm{A}$ and $\mathrm{B} ; 50 \mu \mathrm{m}$ for $\mathrm{C}-\mathrm{H}$. 
the embryonic chicken brain was found in several visual structures including theoptic tectum, the nucl eus suprarotundus, the nucleus marginalis of the optic tract, the nucleus rotundus, and the nucleus isthmi. R-cadherin expression has also been studied in embryonic mouse brain (Matsunami and Takeichi, 1995; Stoykova et al., 1997). Similar to chicken and zebrafish brains, R-cadherin expression was detected at E12.5 in some visual structures, including the suprachiasmaticarea in thehypothalamus and areas of the pretectum. Expression was also observed in the lateral thalamus, which contains the lateral geniculate nucleus, the major retinal target in mammals, although there was no expression at E12.5 in the mouse mesencephal on including the superior colliculi, the mammalian homologue of the optic tectum. However, in the mouse, retinal axons do not reach the superior colliculi until E 15 (Godement et al., 1984; Edwards et al., 1986). In zebrafish, R-cadherin expression was not found in tectal cells until $40 \mathrm{hpf}$, only a few hours before retinal axons arrive in the tectum, so it is possible that R-cadherin may be expressed in mouse superior colliculi at later stages.

\section{CONCLUSIONS}

We have isolated partial cDNAs encoding a novel zebrafish cadherin that is most similar in sequence and in devel opmental expression pattern to R-cadherin in chicken and mouse. Zebrafish R-cadherin is expressed in visual structures and in selected other brain regions of both embryonic and adult zebrafish. Our results demonstrate a close correlation between R-cadherin expression patterns and the developmental profile of retinal ganglion cell differentiation and axon outgrowth, suggesting that Rcadherin may regulate visual system development. This idea is explored further in the following companion paper (Liu et al., 1999).

\section{ACKNOWLE DGMENTS}

We thank Drs. Stephen S. Easter and Grant S. Mastick for their critical comments on the manuscript, and we thank Linda K. Barthel for expert technical assistance. We also thank Dr. J ames Hurley for the generous gift of the adult zebrafish retinal cDNA library, and Dr. BruceAppel for the generous gift of the 15- to 19-hour zebrafish embryo CDNA library. Dr. Benjamin Geiger kindly provided a CDNA coding for zebrafish $\mathrm{N}$-cadherin. This research was supported by EY11365 (] .A. Marrs), EY04318 (P.A. Raymond), and NRSA EY06892 (Q. Liu).

\section{LITERATURE CITED}

Arndt K, Redies C. 1996. Restricted expression of R-cadherin by brain nuclei and neural circuits of the developing chicken brain. J Comp Neurol 373:373-399.

Barthel LK, Raymond PA. 1990. Improved method for obtaining 3- $\mu$ m cryosections for immunocytochemistry. J Histochem Cytochem 9:13831388.

Barthel LK, Raymond PA. 1993. Subcellular localization of alpha-tubulin and opsin mRNA in the goldfish retina using digoxigenin-labeled CRNA probes detected by alkaline phosphatase and HRP histochemistry. J Neurosci Methods 50:145-52.

Bernhardt RR, Chitnis AB, Lindamer L, Kuwada J Y. 1990. Identification of spinal neurons in the embryonic and larval zebrafish. J Comp Neurol 302:603-616.
Bitzur S, Kam Z, Geiger B. 1994. Structure and distribution of N-cadherin in developing zebrafish embryos: morphogenetic effects of ectopic over-expression. Dev Dyn 201:121-136.

Braford MR, J r, N orthcutt RG. 1983. Organization of the diencephalon and pretectum of the ray-finned fishes. I n: Davis RE, Northcutt RG, editors. Fish neurobiology, vol 2. Ann Arbor: University of Michigan Press. p 117-163.

Burrill J D, Easter SS, J r. 1994. Development of the retinofugal projections in the embryonic and larval zebrafish (Brachydanio rerio). J Comp Neurol 346:583-600.

Burrill J D, Easter SS, J r. 1995. The first retinal axons and their microenvironment in zebrafish: cryptic pioneers and the pretract. J Neurosci 15:2935-2947.

Chitnis AB, Kuwada J Y. 1990. Axogenesis in the brain of zebrafish embryos. J Neurosci 10:1892-1905.

Delong GR, Coulombre AJ . 1965. Development of the retino-tectal topographic projection in the chick embryo. Exp Neurol 13:351-363.

Easter SS, J r, Nicola GN. 1996. The development of vision in the zebrafish. Dev Biol 180:646-663.

Edwards MA, Schneider GE, Caviness VS, J r. 1986. Development of the crossed retinocollicular projection in themouse. J Comp Neurol 248:410421.

Gänzler S II, Redies C. 1995. R-cadherin expression during nucleus formation in chicken forebrain neuromeres. J Neurosci 15:4157-4172.

Godement P, Salaün J , Imbert M. 1984. Prenatal and postnatal development of retinogeniculate and retinocollicular projections in the mouse. J Comp Neurol 230:552-575.

Goldberg S. 1974. Studies on the mechanics of development of the visual pathways in the chick embryo. Dev Biol 36:24-43.

Halfter W, Deiss S, Schwarz U. 1985. The formation of the axonal pattern in the embryonic avian retina. J Comp Neurol 232:466-480.

Hatta K, Takeichi M. 1986. Expression of N-cadherin adhesion molecules associated with early morphogenetic events in chick development. Nature 320:447-449.

Hatta K, Takagi S, Fujisawa H, Takeichi M. 1987. Spatial and temporal expression pattern of $\mathrm{N}$-cadherin cell adhesion molecules correlated with morphogenetic processes of chicken embryos. Dev Biol 120:215227.

Hatta K, NoseA, Nagafuchi A, Takeichi M. 1988. Cloning and expression of cDNA encoding a neural calcium-dependent cell adhesion molecule: its identity in the cadherin gene family. J Cell Biol 106:873-881.

$\mathrm{Hu}$ MJ , Easter SS, J r. 1999. Retinal neurogenesis: the formation of the initial central patch of postmitotic cells. Dev Biol 207:309-321.

Hutton J C, Christofori G, Chi WY, Edman U, Guest PC, Hanahan D, Kelly RB. 1993. Molecular cloning of mouse pancreatic islet R-cadherin: differential expression in endocrine and exocrine tissue. Molec Endocrinol 7:1151-1160.

Inoue T, Sanes JR. 1997. Lamina-specific connectivity in the brain: regulation by $\mathrm{N}$-cadherin, neurotrophins, and glycoconjugates. Science 276:1428-1431.

Inoue T, Tanaka T, Suzuki SC, Takeichi M. 1998. Cadherin-6 in the developing mouse brain: expression along restricted connection systems and synaptic localization suggest a potential role in neuronal circuitry. Dev Dyn 211:338-351.

Inuzuka H, Miyatani S, Takeichi M. 1991. R-cadherin: a novel $\mathrm{Ca}^{2+}$ dependent cell-cell adhesion molecule expressed in the retina. Neuron 7:69-79.

J essell TM. 1988. Adhesion molecules and the hierarchy of neural development. Neuron 1:3-13.

J owett T, Mancera M, Amores A, Yan YL. 1996. In situ hybridization to embryo whole mounts and tissue sections: mRNA detection and application to developmental studies. I n: Clark M, editor. In situ hybridization. London; New York: Chapman and Hall. p 91-121.

Kaethner RJ , Stuermer CAO. 1992. Dynamics of terminal arbor formation and target approach of retinotectal axons in living zebrafish embryos: a time-lapse study of singleaxons. J Neurosci 12:3257-3271.

Kimmel CB. 1993. Patterning the brain of the zebrafish embryo. Ann Rev Neurosci 16:707-732.

Kuwada J Y, Bernhardt RR, Nguyen N. 1990. Development of spinal neurons and tracts in the zebrafish embryo. J Comp Neurol 302:617628.

Laessing U, Stuermer CAO. 1996. Spatiotemporal pattern of retinal ganglion cell differentiation revealed by the expression of neurolin in embryonic zebrafish. J Neurobiol 29:65-74. 
Liu X, Mizoguchi A, Takeichi M, Honda Y, Ide C. 1997. Developmental changes in the subcellular localization of R-cadherin in chick retinal pigment epithelium. Histochem Cell Biol 108:35-43.

Liu Q, Marrs J A, Raymond PA. 1999. Spatial correspondence between R-cadherin expression domains and retinal ganglion cell axons in developing zebrafish.J Comp Neurol 410:290-302.

Marrs J A, Napolitano EW, Murphy-Erdosh C, Mays RW, Reichardt LF, Nelson WJ . 1993. Distinguishing roles of the membrane-cytoskeleton and cadherin mediated cell-cell adhesion in generating different $\mathrm{Na}^{+}$, $\mathrm{K}^{+}$-ATPase distributions in polarized epithelia. J Cell Biol 123:149164.

Matsunaga M, Hatta K, Takeichi M. 1988a. Role of N-cadherin cell adhesion molecules in the histogenesis of neural retina. Neuron 1:289295.

Matsunaga M, Hatta K, Nagafuchi A, Takeichi M. 1988b. Guidance of optic nerve fibers by N-cadherin adhesion molecules. Nature 334:62-64.

Matsunami H, Takeichi M. 1995. Fetal brain subdivisions defined by R- and $\mathrm{E}$-cadherin expressions: evidence for the role of cadherin activity in region-specific, cell-cell adhesion. Dev Biol 172:466-478.

Matsunami H, Miyatani S, Inoue T, Copeland NG, Gilbert DJ . 1993. Cell binding specificity of mouse R-cadherin and chromosomal mapping of the gene. J Cell Sci 106:401-409.

MCLoon SC, Barnes RB. 1989. Early differentiation of retinal ganglion cells: an axonal protein expressed by premigratory and migrating retinal ganglion cells. J Neurosci 9:1424-1432.

Nawrocki LW. 1985. Development of the neural retina in the zebrafish, Brachydanio rerio. Doctoral dissertation, University of Oregon, Eugene.

Redies C. 1995. Cadherin expression in the developing vertebrate CNS: from neuromeres to brain nuclei and neural circuits. Exp Cell Res 220:243-256.

Redies C. 1997. Cadherins and the formation of neural circuitry in the vertebrate CNS. Cell Tissue Res 290:405-413.

Redies C, Takeichi M. 1993a. N-and R-cadherin expression in the optic nerve of the chicken embryo. Glia 8:161-171.

Redies C, Takeichi M. 1993b. Expression of N-cadherin mRNA during development of the mouse brain. Dev Dyn 197:26-39.

Redies C, Takeichi M. 1996. Cadherins in the developing central nervous system: an adhesive code for segmental and functional subdivisions. Dev Biol 180:413-423.

Redies C, Inuzuka H, Takeichi M. 1992. Restricted expression of N- and R-cadherin on neurites of the developing chicken CNS. J Neurosci 12:3525-3534.

Redies C, Engelhart K, Takeichi M. 1993. Differential expression of N- and $\mathrm{R}$-cadherin in functional neuronal systems and other structures of the developing chicken brain. J Comp Neurol 333:398-416.

Ross LS, Parrett T, Easter SS, J r. 1992. Axonogenesis and morphogenesis in the embryonic zebrafish brain.J Neurosci 12:467-482

Rupp B, Wullimann MF. 1996. The zebrafish brain: a neuroanatomical comparison with the goldfish. Anat Embryol 194:187-203.

Sambrook J , Fritsch EF, Maniatis T. 1989. Molecular cloning. Cold Spring Harbor, NY: Cold Spring Harbor Laboratory Press.
Schmitt EA, Dowling J E. 1996. Comparison of topographical patterns of ganglion and photoreceptor cell differentiation in the retina of the zebrafish, Danio rerio. J Comp Neurol 371:222-234.

Shimamura K, Hartigan DJ , Martinez S, Puelles L, Rubenstein J LR. 1995 Longitudinal organization of the anterior neural plate and neural tube. Development 121:3923-3933.

Singleton CD, Casagrande VA. 1996. A reliable and sensitive method for fluorescent photoconversion. J Neurosci Methods 64:47-54.

Stoykova A, Gtöz M, Gruss P, Price J . 1997. Pax6-dependent regulation of adhesive patterning, R-cadherin expression and boundary formation in developing forebrain. Development 124:3765-3777.

Striedter G, Northcutt RG. 1989. Two distinct visual pathways through the superficial pretectum in a percomorph teleost. J Comp Neurol 283:342354.

Stuermer CAO. 1988. Retinotopic organization of the developing retinotectal projection in the zebrafish embryo. J Neurosci 8:4513-4530.

Stuermer CAO, Rohrer B, Münz H. 1990. Development of the retinotectal projection in zebrafish embryos under TTX-induced neural impulse blockade. J Neurosci 10:3615-3626.

Takeichi M. 1988. The cadherins: cell-cell adhesion molecules controlling animal morphogenesis. Development 102:639-655.

Takeichi M. 1990. Cadherins: a molecular family important in selective cell-cell adhesion. Ann Rev Biochem 59:237-252.

Takeichi M. 1991. Cadherin cell adhesion receptors as a morphogenetic regulator. Science 251:1451-1455.

Takeichi M. 1995. Morphogenetic roles of classic cadherins. Curr Opin Cell Biol 7:619-627.

Tanihara H, Sano K, Heimark RL, St J ohn T, Suzuki S. 1994. Cloning of five human cadherins clarifies characteristic features of cadherin extracellular domain and provides further evidence for two structurally different types of cadherin. Cell Adh Comm 2:15-26.

Tashiro K, Tooi TO, Nakamura H, Koga C, I to Y, Hikasa H, Shiokawa K. 1995. Cloning and expression studies of cDNA for a novel Xenopus cadherin (XmN-cadherin), expressed maternally and later neuralspecifically in embryogenesis. Mech Dev 54:161-171.

von Bartheld CS, Cunningham DE, Rubel EW. 1990. Neuronal tracing with Dil: decalcification, cryosectioning, and photoconversion for light and electron microscopic analysis. J Histochem Cytochem 38:725-733.

Westerfield M. 1996. The zebrafish book. Eugene: University of Oregon Press.

Wilson SW, Ross LS, Parrett T, Easter SS, J r. 1990. The development of a simple scaffold of axon tracts in the brain of the embryonic zebrafish, Brachydanio rerio. Development 108:121-145.

Wohrn J CP, Puelles L, Nakagawa S, Takeichi M, Redies C. 1998. Cadherin expression in the retina and retinofugal pathways of the chicken embryos. J Comp Neurol 396:20-38.

Wullimann MF, Meyer DL. 1990. Phylogeny of putative cholinergic visual pathways through the pretectum to the hypothalamus in teleost fish. Brain Behav Evol 36:14-29.

Wullimann MF, Rupp B, Reichert H. 1996. Neuroanatomy of the zebrafish Danio rerio: a topological atlas. Basel: Birkhäuser. 